\title{
Some Explanations for Changes in the Distribution of Household Income in Slovakia: 1988 and 1996
}

\author{
By: Thesia Garner and Katherine Terrell
}

Working Paper No. 377

May 2001 


\title{
SOME EXPLANATIONS FOR CHANGES IN THE DISTRIBUTION OF HOUSEHOLD INCOME IN SLOVAKIA: 1988 AND 1996
}

\author{
Thesia I. Garner* \\ Division of Price and Index Number Research \\ Postal Square Building, Room 3105 \\ Bureau of Labor Statistics \\ 2 Massachusetts Avenue \\ Washington, D. C. 20212 \\ U.S.A. \\ Garner_T@BLS.gov \\ Telephone: (202) 691-6576 \\ Fax: (202) 691-6583 \\ and \\ Katherine Terrell \\ William Davidson Institute and \\ University of Michigan Business School \\ Ann Arbor, MI 48109 \\ U.S.A. \\ terrell@umich.edu \\ Telephone: (734) 615-4558 \\ Fax: (734) 936-8715
}

May 2001

\footnotetext{
*The views expressed are those of the author and do not reflect the policies of the Bureau of Labor Statistics (BLS) or the views of other BLS staff members.
} 


\begin{abstract}
This paper measures the change in overall net monetary income inequality during the first seven years of transition and considers the relative importance of two possible explanations for the increase in inequality: a) changes in the sources of household income, and b) changes in the household composition. Changes in the sources of household income reflect the role of the government and market during the transition period, while changes in household composition reflect social reactions to the changing economic environment. We find that the increase in inequality in labor income drove the large increase in inequality (i.e., the Gini index of household per capita income rose from 0.195 in 1988 to 0.263 in 1996). Changes in the distribution of pensions and other social payments mitigated the rise in earnings inequality, with the latter playing a more role in reducing changes overall income inequality over time. We show there are large shifts in the demographic composition of households over this period: far fewer households with children, far more households headed by pensioners, increases in the number of oneperson households and decreases in large (five person) households. Although we find that these shifts in the demographic composition of households are increasing overall inequality, by increasing between group inequality, most of the change in inequality over time is accounted for by increase in within group inequality. We conclude that over the first seven years of the transition labor market forces are driving changes in overall inequality in Slovakia to a much greater extent than changes in the Government's social safety net or in individual's decisions about household formation.
\end{abstract}




\section{Non-Technical Summary}

In this paper we measure the extent to which income inequality increased in Slovakia from 1988 to 1996 and we examine two potential explanations for the increase in inequality over this period: a) changes in the sources of household income, and b) changes in the household composition. Changes in the sources of household income reflect the role of the government and market during the transition period, while changes in household composition reflect social reactions to the changing economic environment.

We compare inequality before the transition began, in 1988, to the level of inequality eight years later using Microcensus data, and four measures of inequality (the Gini, the Theil, the coefficient of variation and the mean log deviation) and three measures of adult-equalent income (the OECD, the Luxemburg Income Study and the per capita measures). We find a significant rise in non-monetary income inequality. For example, the Gini index of household per capita income rose from 0.195 in 1988 to 0.263 in 1996.

To examine the extent to which different sources of income explain the increase in overall income inequality, we decompose the Gini using the Lerman and Yitzhaki $(1985,1989,1994)$ decomposition method. We find that changes in the distribution of non-agricultural earnings explain the lion's share of the increase in overall inequality. Changes in the distribution of pensions and other social payments mitigated the rise in earnings inequality, with the latter playing a more role in reducing changes overall income inequality over time. 
We show there are large shifts in the demographic composition of households over this period: far fewer households with children, far more households headed by pensioners, increases in the number of one-person households and decreases in large (five person) households. In order to analyze the effect of changes in the demographic composition of households on income inequality we decompose the mean log deviation index of inequality for within group and between group changes over time (Shorrocks, 1984). Although we find that the shifts in the demographic composition of households are increasing overall inequality, by increasing between group inequality, most of the change in inequality over time is accounted for by increase in within group inequality.

We conclude that over the first seven years of the transition labor market forces are driving changes in overall inequality in Slovakia to a much greater extent than changes in the Government's social safety net or in individual's decisions about household formation.

\section{Introduction}

Under the Soviet system, the Central and East European (CEE) countries maintained the most equal distributions of income in the world. Hence greater income inequality was an expected outcome of a transition from a command to a market economy. Indeed, as prices were liberalized and market forces unleashed, workers with scarce skills saw their earnings rise, while others suffered severe declines in their earnings and even unemployment (see e.g., Terrell, 1999 for a description of winners and losers in the emerging labor market of transition economies).

As expected, we find in our earlier study (Garner and Terrell, 1998) that Slovakia experienced a substantial increase in the inequality of labor earnings during the first four 
years of transition (1989-1993), however the surprizing result was the very small increase in overall income inequality. Gini coefficient for total household per capita rose from 0.157 to 0.168 over this period, whereas the Gini for the per capita earnings from labor rose from 0.281 to 0.344 (with much of the rise resulting from self-employment income). The increase in total income inequality arising from this earnings component was almost completely mitigated by changes in the incidence of taxes and distribution of transfers, with the former playing a slightly more important role than the latter.

In this paper we build on our earlier work to learn about the extent to which inequality increased as the transition progressed to 1996 and to examine some potential explanations for the increase in inequality over this period. We compare inequality before the transition began, in 1988, to the level of inequality eight years later using Microcensus data. This is a larger database than the $F B S$ which we used earlier and it is designed to be representative of the total population with its own set of weights. ${ }^{\text {As in }}$ our previous work, we decompose changes in total inequality by changes in sources of income (i.e., earnings from labor, versus transfer income). In this way we can examine the extent to which the labor market affected the distribution of income and the role that the government played in providing a social safety net in 1996 compared to 1988 (and to 1993). Moreover, in this paper we explore an additional factor: the extent to which changes in the demographic composition of households may help explain changes in

\footnotetext{
${ }^{1}$ We refer to after-tax income, including in-kind payments.

${ }^{2}$ For our earlier study, we created population weights using the Microcensus and FBS data to make the FBS data as representative as possible. The Central Statistical Office does not produce population weights for the $F B S$.
} 
income inequality over these eight years. The transition process that Slovakia has been undertaking since 1989 has impacted both of these channels of income inequality.

\section{Transition in Slovakia}

The Slovak economy experienced an enormous transformation during the 19881996 period. The macroeconomic statistics in Table 1 indicate the tremendous growth of the private sector as its share of GDP rose from about 5 percent in 1990 to 70 percent in 1996. As in all the Central and East European economies, GDP fell for the first four years of transition (by an average of almost 7 percent a year) but rebounded in 1994 with strong growth through 1996, the end of our period of analysis. Inflation rose by 58 percent during the year that the government liberalized all prices (1991), fell to single digits in 1992 and then rose to 25.7 percent in 1993, the year of the "Velvet Divorce" with the Czech Republic. The decline in output impacted the level of employment, which in 1996 was still only 84.5 percent of the level in 1989. This was accompanied by large sectoral shifts in the structure of employment away from agriculture and industry (including manufacturing and utilities), which declined by 44.2 percent and 26.8 percent, respectively. Employment in the service sector absorbed some but not all of the outflows as it grew by 12.1. (Slovak Statistical Yearbook, 1997.) Hence unemployment rates were fairly high -- ranging from 10 percent to 14 percent -- throughout the period under analysis.

As a result of all these structural changes in the economy, individuals were faced with much uncertainty about both their job security and the purchasing power of their income during this period. This uncertainty had an impact on the family formation and 
household structure of the Slovakian people. As seen in Table 2, marriage rates and birth rates declined tremendously from 1989 to 1996, while the divorce rate rose only slightly over the time period. Not surprisingly, the rate of natural increase (the rate at which the population grows based on birth and death rates) fell from 5.0 to 1.6 over this period. Unlike the dramatic case of Russia, where the male mortality rate rose during the transition, the death rate and the infant mortality rate fell over the period.

In this paper we examine how this changing environment affected the distribution of income over time. After measuring the change in overall inequality, we consider the relative importance of two possible explanations for the increase in inequality: a) changes in the sources of household income, and b) changes in the household composition. Changes in the sources of household income reflect the role of the government and market during the transition period, while changes in household composition reflect social reactions to the changing environment. We note that these changes affect the distribution of total income by changing both the numbers of people in different demographic groups as well as the distribution of incomes per se.

\section{Methods and Data}

\subsection{Data}

The data for this analysis are from the Microcensuses taken in 1989 and 1997. Data for each survey refer to income in each previous year. The sample for the first survey represents approximately 5 percent of the households who were living in Slovakia in 1988 (a subsample of the one used for the Czechoslovak Microcensus). The unit of sample selection is the house or apartment. Data are available by common budget households, defined as a set of persons in the same dwelling who share the main 
household expenditures. People living in the dwelling declared their status according to how they shared expenditures (Atkinson and Micklewright, 1992). The sample for the 1997 Microcensus was created by selecting one percent of all households living in Slovakia in 1997 following a similar procedure as was used for the earlier surveys (Slovak Central Statistical Office website 2001). The 1988 data set includes information on 31,600 households and the 1996 data set includes data on 16,336 households.

\subsection{Inequality Measurement}

Our analysis of overall inequality uses Lorenz curves (L) and inequality indices based on rankings of weighted population samples. The indices include the standard Gini coefficient $(\mathrm{G})$ and three generalized entropy measures: one half the square of the coefficient of variation (CV), the Theil coefficient (T), and the mean logarithmic

deviation (D). ${ }^{\text {B }}$ The Lorenz curve for discrete distributions, in our case deciles, can be defined as:

$$
L\left(\frac{j}{10}\right)=\sum_{i=1}^{10} \frac{\boldsymbol{Y}_{i}}{\boldsymbol{Y}} \text { where } \quad 1 \leq j \leq 10 \text { and } \boldsymbol{Y}=\sum_{i=1}^{10} \boldsymbol{Y}_{i}
$$

(Lambert 1993, p. 40.) The indices of inequality can be defined as:

$$
\begin{aligned}
& \mathrm{G}=\sum_{i} \sum_{j} \frac{\left|Y_{i}-Y_{j}\right|}{2 n^{2} \bar{Y}} \\
& \mathrm{CV}=\frac{1}{2 n} \sum_{i=1}^{n}\left[\left(\frac{Y_{i}}{\bar{Y}}\right)^{2}-1\right]
\end{aligned}
$$

\footnotetext{
${ }^{3}$ For definitions of these measures of inequality see Coulter et al., 1992
} 


$$
\begin{gathered}
\mathrm{T}=(1 / n) \sum_{i=1}^{n}\left(Y_{i} / \bar{Y}\right) \ln \left(Y_{i} / \bar{Y}\right) \\
\mathrm{D}=(1 / n) \sum_{i=1}^{n} \ln \left(\bar{Y} / Y_{i}\right)
\end{gathered}
$$

where $Y_{i}=$ the rank weighted income, $\bar{Y}=$ the mean income, and $n=$ the number of income units (persons in the population in our case). Each of the overall measures differs in its sensitivity to income variations at different levels of the distribution. For equidistant transfers, the Gini index is considered to be more sensitive to transfers around the mode, while the Theil measure and one-half the square of the coefficient of variation are more sensitive to transfers at the top of the distribution. The mean logarithmic deviation is relatively more responsive to transfers at the lower end of the distribution.

If the values of all the indices are higher in year $t$ than they are in year $t$ - 1 , then it can be said that the distribution of income is more unequal in year $t$. When one Lorenz curve lies above another at one or more points, and does not lie below it at any point, then there is clear Lorenz dominance. However, if one Lorenz curve crosses the other, no conclusions can be drawn regarding relative inequality.

Household data from the Microcensus are the basis of our analysis. However, since the focus of this research is the inequality of income across individuals, we allocate adjusted household income to each household member. This weighting results in the individual distribution rather than household distribution of income. The amount of adjusted (or "equivalent") income per person in each household unit is calculated by dividing total household income by the number of equivalent adults in the household. We examine the robustness of our results using four different equivalence scales:

- the OECD equivalence scale 
first adult receives a weight of 1 , each additional adult receives a weight of 0.7 , and each child a weight of 0.5

- the Luxembourg Income scale (LIS)

the square root of household size

- $\quad$ per capita $(\mathrm{PC})$ adjustment

each person receives a weight of one

\subsection{Decomposition Analysis}

We undertake two types of decompositions in order to understand which factors are important in contributing to the levels of inequality in each year and changes in inequality over time. The first decomposition is by sources of income and the second is by demographic composition of the household.

Total household income is defined as the sum of monetary income net of taxes (wage and other taxes and fees) plus the cash value of in-kind income. ${ }^{\text {We analyze the }}$ following six sources of income for 1988 and 1996:

\section{- Earned Income}

1. Earnings from any non-agricultural employment ("wage income")

2. Earnings from agricultural employment

\section{- Social Payments}

3. Pensions

4. Other social payments which include: ${ }^{6}$

- Sickness Related Benefits (which include income from health insurance and financial support while taking care of a family member);

- Unemployment Benefits (in 1996 only)

- Child Allowances

- Social Assistance and Other Family Benefits (including maternity leave, and parental allowances)

\footnotetext{
${ }^{4}$ We were unable to analyze taxes since this was available separately only in 1988.

${ }^{5}$ This includes income from the self-employed. We would have liked to analyze self-employment income separately but this was not possible given the construction of the data set in 1988 .

${ }^{6}$ We are unable to separate out the distributional impact of the subgroups of social payments over time since the categories in 1988 are not comparable to those in 1996.
} 


\section{- Other Income}

5. In-kind income

6. Other monetary income, which includes income from property, institutions or private persons and income from abroad.

To analyze the share of inequality due to each of these sources of income, we use the Lerman and Yitzhaki $(1985,1989,1994)$ decomposition of the Gini. and Yitzhaki method decomposes the Gini into three terms: the Gini of the factor component $\left(\mathrm{G}_{\mathrm{g}}\right)$, the correlation of the factor component with the cumulative distribution of overall income $\left(\mathrm{R}_{\mathrm{g}}\right)$, and the share of the factor component in overall income, $\left(\mathrm{S}_{\mathrm{g}}\right)$ :

$$
G=\sum_{g=1}^{G} G_{g} R_{g} S_{g}
$$

where:

$$
\begin{aligned}
& G_{g}=\frac{2 \operatorname{cov}\left\lfloor y^{g}, F^{g}\right\rfloor}{y^{g}}, \\
& R_{g}=\frac{\operatorname{cov}\left\lfloor y^{g} F\right\rfloor}{\operatorname{cov}\left[y^{g}, F^{g}\right]} \\
& S^{g}=\frac{\bar{y}^{g}}{\bar{Y}}
\end{aligned}
$$

where $\mathrm{y}^{1} \ldots \mathrm{y}^{\mathrm{g}}$ represent the income levels of factor components $g, \mathrm{~F}^{\mathrm{g}}$ represents the cumulative distribution of $\mathrm{y}^{\mathrm{g}}$ and $\overline{\boldsymbol{Y}}^{g}$ represents the mean. F is the cumulative distribution of $Y$ and $\bar{Y}$ is the mean of overall income.

In order to analyze the effect of the demographic composition of households on income inequality we decompose two indices, which are members of the Generalized

\footnotetext{
${ }^{7}$ Lerman (1999) wrote in a recent survey article, "It is now well understood that the seemingly simple question "what is the role of an income source in overall income inequality' is complex." Surely, part of the
} 
Entropy (GE) measures of inequality measures, the Theil and the mean log deviation indices. Both are additively decomposable by population subgroups (Shorrocks, 1984). To define these indices, let the population be partitioned into $k$ mutually exclusive subgroups, for example, household composition. The additive decomposability of $\mathrm{T}$ and $\mathrm{D}$ can be illustrated by re-writing equations (4) and (5) as follows:

$$
\mathrm{T}=\sum_{k} r_{k} T_{k}+\sum_{k} r_{k} \ln \left[\lambda_{k}\right]
$$

and

$$
D=\sum_{k} v_{k} D_{k}+\sum_{k} v_{k} \ln \left(1 / \lambda_{k}\right)
$$

where $\boldsymbol{r}_{\boldsymbol{k}}=\frac{\boldsymbol{n}_{\boldsymbol{k}} * \overline{\boldsymbol{Y}_{\boldsymbol{k}}}}{\boldsymbol{n}^{*} \boldsymbol{\overline { Y }}}$ is the contribution of group $k$ to overall income, $\boldsymbol{v}_{\boldsymbol{k}}=n_{k} / n$ is the population share of group $k, \lambda_{k}=\bar{Y}_{k} / \bar{Y}$ is group $k$ 's mean income. For each index presented in (7) and (8), total inequality can be expressed as the sum of two contributions: the first term being the "within-group" component (the weighted sum of the inequalities within each sub-group) and the second term is the "between group" component (the inequality remaining were each person's income to be equal to his/her sub-group's mean income).

We decompose inequality changes and focus on the mean log deviation measure since is provides a more useful decompositional formulation than does the Theil. ${ }^{8}$ The change in inequality over the two years, $t$ and $t+l$ can be written as

$$
\Delta_{0} \approx \sum_{k} \bar{v}_{k} \Delta I_{0 k}+\sum_{k} \bar{I}_{0 k} \Delta v_{k}+\sum_{k} \overline{\left.\bar{\lambda}_{k}-\overline{\ln \left(\lambda_{k}\right)}\right)} \Delta_{v_{k}} \quad \sum_{k}\left(\bar{\theta}_{k}-\bar{v}_{k}\right) \Delta \ln \left(\bar{Y}_{k)}\right)
$$

difficulty is that "a source's contribution to inequality depends not only on aspects of the source itself but also on how it interacts with other sources." However, this does not invalidate the source decomposition. ${ }^{8}$ According to Jenkins (1995). 


$$
\text { term } \mathrm{A} \text { term } \mathrm{B} \text { term } \mathrm{C} \text { term } \mathrm{D}
$$

The change operator is $\Delta$, and a bar over a variable represents the arithmetic mean of the

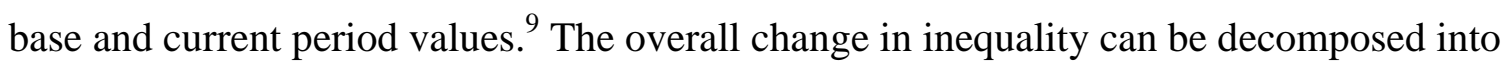
four parts: term A represents the impact of 'pure' within-group inequality changes over time; terms $\mathrm{B}$ and $\mathrm{C}$ represent the effect on overall inequality of changes in the population shares on the 'within group' and 'between group' components, respectively. Term D represents relative changes in the subgroup means.

\section{4. $\quad$ Findings}

The startling finding in this paper is how much income inequality increased over 1993-1996 period compared to the 1988/9-93 period. Whereas we (Garner and Terrell, 1998) found total household per capita income inequality did not increase appreciably from 1989 to 1993 , we now find that over the 1988-1996 period it has grown by a relatively large amount. As indicated in Table 3, the Gini indices rise by at least 33 percent between 1988 and 1996 when the per capita Gini rose by only 7 percent between 1989 and 1993. The other measures of inequality (Theil, coefficient of variation and the mean log deviation) essentially double in size between 1988 and 1966.10 We also note that the 1996 Lorenz curve, plotted in Chart 1, shifts out to the right of the 1988 Lorenz curve at each point. In looking for explanations for this rise in inequality, we begin by examining changes in the sources of income.

\footnotetext{
${ }^{9}$ Mookherjee and Shorrocks (1992) are credited for creating the decomposition. See Jenkins (1995) for a further application.

${ }^{10}$ We note that in almost all cases the per capita income measures are higher than are those using the OECD and LIS adult equivalent adjustments.
} 


\subsection{Sources of Income}

As noted above, we examine six sources of after-tax income: income from labor (subdivided into agricultural and non-agricultural income), social transfers (subdivided into pensions and other social payments) and other income (in-kind income and other monetary income). We describe in this section the distributions of each of these sources of income in 1988 and 1996 using various methods presented in Tables 4 and 5 and Charts 1 through 5.11 Table 4 contains information on the share of income from each of the six sources across all persons within each decile of the income distribution. For example, 23.5 percent of all income is from non-agricultural sources for persons in decile 1 in 1988. Table 5 presents results from the decomposition described in equations (6a) to (6c). Charts 1, 2 and 4 present the Lorenz and Concentration curves of each source of income. Finally, Charts 3 and 5 provide information on the percentage of households in each decile that have a positive value for a particular source of income.

Clearly the first place to look for an explanation of the significant increase in total income inequality is in the change in the distribution of earnings from labor. A comparison of the top with the bottom half of Chart 1, indicates that the distance between the 1996 and 1988 concentration curves for earned income is greater than the distance between the Lorenz curves for total income, indicating a increase in the concentration of earned income over this time period. ${ }^{12}$ Decomposing earned income into two sources -agricultural and non-agricultural -- and plotting their concentrations curves for each year, we learn that the distribution of earnings from non-agricultural activity has become far

\footnotetext{
${ }^{11}$ The results in this section (in Charts 1-5 and in Tables 4 and 5) are based on person-weighted, adultequivalent (LIS) incomes.

${ }^{12}$ Hence, the relative change in inequality between earned ant total income over time is qualitatively similar using the 1988-1996 the Microcensus data and the 1989-1993 Family Budget Survey data.
} 
more concentrated among the higher income groups over time whereas earnings from agricultural income have become less concentrated over the household income distribution in 1996 than in 1988 (Chart 2).

The numbers in Table 5 indicate that earned non-agricultural income contributes more to total income inequality than any other source in both years and its contribution has risen over time from 0.147 to 0.255 . This is the largest increase from any source of income. On the other hand, earned agricultural income played a small role in overall inequality in 1988, contributing 0.045 to the overall Gini, and an even smaller role in 1996, contributing only 0.004 .

We then ask which factor might be driving the changes in the contributions of non-agricultural and agricultural income to overall household income inequality -changes in the inequality of that source per se or changes in the shares of the population earning that component of income? As seen in Chart 3, in 1988 the percentage of households with earnings from non-agricultural activity was about the same in all deciles (approximately 90 percent of the households in each of the top seven deciles) but in 1996, the percentages of households with non-agricultural earnings is not as equally distributed: Whereas in 1996, 90 percent of the households in the top four deciles continue to earn non-agricultural income, the proportion fell to 80 percent, 70 percent , and 60 percent for the next three deciles, respectively. I.e., a smaller share of households in the second to the sixth deciles earn non-agricultural income in 1996 compared with 1988 (Table 4).

The increased contribution to total inequality from non-agricultural income over time (from 0.147 to 0.255 ) seems to be driven by the increase in its inequality (rising from 0.362 to 0.458 ) and a decline in the share of individuals with this income (from 85.0 
percent to 78.4 percent). Because that decline in the share of individuals with this income was in the lower half of the distribution, the average share of income from nonagricultural activities that the households receive over the eight-year period did not change much, and actually rose somewhat, from 0.622 in 1988 to 0.678 in 1996 (Table $5) .13$

The decreased contribution of agricultural income to total household income arises largely because the share of total income from agriculture for households fell from 0.094 to 0.013 and the person shares fell from 20.1 percent to 3.9 percent (Table 5). As seen in Chart 3, the shares of households with some agricultural income declined from 1988 to 1996 . We also see that the person weighted share of total income from agriculture within each decile fell over time (Table 4). The distribution of agricultural income seems to have become slightly more unequal as the factor Gini rose by only 11 percent (as compared to 27 percent for non-agricultural income) as seen in Table 5. Although agricultural income became more unequal over the time period, it became less concentrated among the higher income groups.

The income shortfall created by the decline in the overall share of agricultural earnings and the decline in the share of non-agricultural earnings for the lower half of the distribution was filled by pension income, which became a larger share of total household weighted income (rising from 0.124 to 0.180 ) and of person weighted income (rising from 0.345 to 0.379 ) over the time period (Table 5). As seen in Table 4, this is due to the rising share of pension income in each decile, except for the top and bottom ones. The concentration curves for pension income (Chart 4) indicates that it is becoming less concentrated relative to overall income, as pension income was previously

\footnotetext{
${ }^{13}$ If someone in the household received the income, a share was allocated to each person therein.
} 
skewed to the lower end of the distribution. The curve above the equal line indicates that pensions are concentrated among those who are poorer or at the end of the income distribution. In 1988, pensions were more concentrated among people in the lower end of the income distribution. By 1996, those at the lower end of the distribution were receiving a disproportionate lower share of pension income up until about the $30^{\text {th }}$ percentile. After that point, pensions became a larger share relative to population ranking based on overall income. For example, in 1996, 80 percent of the population had access to about 85 percent of all pension income. In contrast, in 1988, pension incomes were equally concentrated among the population at the 80 percentile.

There was a decrease in the factor Gini for pension income from 1988 to 1996 from 0.755 to .730 (Table 5). However, the overall effect of the distribution pension income on total income inequality and the difference over time is small: in 1988 it contributed to lowering inequality by 0.016 and in 1996 the contribution was -0.012 (Table 5).

Although other social payments have fallen as a share of household and person weighted income, from 0.111 to 0.083 for household weighted income and 0.825 to 0.552 for persons weighted income (Table 5), they are more targeted to the lower end of the distribution by 1996. As seen in Table 4, the share of other social payments as a percent of person weighted household income has fallen in the top eight deciles and risen dramatically (from 11 percent to 31 percent for the lowest decile). For the second decile, the increase was only slight. Similarly for households, Chart 5 indicates the share of households with any other social income payments fell in all categories except the lowest decile, where it rose. As seen in Chart 4, in 1988 the poorest 20 percent of the 
population received less than its share of other social payments, while the top half of the distribution received more. However the concentration curve in 1988 hovers around the 45-degree line. Finally, the increasing importance of other social payments to total inequality is seen in Table 5: whereas these payments reduced total inequality by only 0.001 in 1988 , in 1996 they lowered total inequality by 0.015 .

Although net monetary income is only a small share of total household income in both years (0.011 and 0.024 at the household level and 0.184 and 0.105 at the person level), its share at the top two deciles rose considerably in 1996 (see Table 4). Similarly, the share of households with net monetary income fell in all but the top decile where it rose (Chart 5). The 1996 concentration curve reveals that other net monetary income is less equally distributed across the total population than such income for 1988. (Chart 4). This source of income is quite eclectic, including earnings from abroad as well as income from property and from other people.

Finally, in-kind income became more equally distributed (and less concentrated) over the total income population (Chart 4). The shares of this income across the deciles fell from 1988 to 1996 but the shares fell in almost the same way (Table 4). The results in Chart 5 reveal a much lower and similarly distributed percentage of households with in-kind income in 1996 as in 1988.

In summary: overall inequality rose during the period, largely due to the rise in the inequality of non-agricultural earned income and partially due to the rise in inequality of other monetary income (which includes foreign income). The rise in the contribution of non-agricultural earnings to total income inequality is likely due to a tremendous rise 
in inequality in the distribution of non-agricultural earnings and a decline both in the share of individuals with this income.

\subsection{Demographic Characteristics of Households}

Among other channels, changes in income inequality can be driven by changes in the composition of the household. The demographic shifts we noted in Table 2, regarding the noticeable decline in the marriage rates and live-births are reflected in the structures of the households in the 1988 and 1996 Microcensus data. For example, we show in Table 6 that the share of the households with one or more children fell to 33 percent in 1996 from 45 percent in 1988. Similarly, we noted above that the death rates declined slightly, yielding higher life expectancy. We find in the Microcensus data that the average age of the head of the household rose as the share of households with heads over 70 years of age increased and the share with heads less than 39 years of age fell.

As a result of the tremendous structural changes in the Slovak economy, with labor being reallocated from the inefficient old state sector to the new private sectors, many people became unemployed or took early retirement. Hence, it is not surprising to note in Table 6 that the head of the household in 1996 is much less likely to be working and more likely to be a pensioner or unemployed compare to 1988 . However, the rise in the share of households headed by pensioners - from 26 percent to 35 percent - could also reflect other factors, such as general aging of the population or a change in household formation, in addition to the increase in the number of pensioners brought about by the restructuring. The figures in Table 7 reveal that the number of pensioners rose by about 10 percent from 1989 to 1995 and that the rise was higher among old-age and disability pensioners (14 percent) than among widows ( 8 percent). As seen in Table 7 , the 
government has maintained the value of pension income by allowing it to rise at the same rate that wages are rising. Hence pensions have been consistently around 45 percent of the average wage over this period. Given these statistics, we question if the Slovak government's decision to maintain the purchasing power of pensioners at a relatively high level has enabled pensioners to live independently, rather than together with their children's family. Consistent with this hypothesis is the finding in Table 6 that there is a decrease in the share of households with five or more persons and an increase in the share with one person.

How do these changes in household composition impact the distribution of income during the 1988 and 1996 periods? We begin to examine this issue by describing the demographic characteristics of the households in each decile in Chart 6. For example, the number of persons per household declined over the period in all but the lowest decile, which in 1996 has more members (2.5) than in 1988 (1.6). This is most likely due to a decline in the number of children per household in each decile, except for the lowest where it rose. Households in the lowest decile are comprised partially of more children, more economically active adults and more unemployed adults (not shown in Chart 6). However, households in the first decile are not composed of more pensioners, The lower right hand chart in Chart 6 indicates that the percentage of households in the first decile with a pensioner head decreased in 1996, while the percentage increased in all other deciles in 1996 relative to 1988.

In order to increase our understanding of the role of demographic characteristics on income inequality, we first decompose overall inequality into the portion due to inequality within each group and the portion arising from the inequality that remained if 
each person's income was equal to her/his sub-group's mean income (i.e., between group inequality). Following this results, we present the results from the inequality decomposition which reflects changes over time.

The findings from the within year decompositions, described in equations (9) and (10), are presented in Table 8. The decompositions are carried out for the six groups previously described in Table 6 plus two new demographic classifications of households based on a combination of the other characteristics.

Not surprising, the decompositions for the Theil and mean log deviation indices show that the majority of overall inequality can be explained by inequality from within the groups -- very little is driven by the between group differences. 14 Moreover, the increase in inequality over time is being driven by changes in within group inequality since in most cases (six out of eight categories) the between group inequality has fallen over time. For example, in the third category, number of economically active members, the inequality within the groups (i.e., none, one, two, three+ members) represented 56 percent of total inequality in 1988 (i.e., $0.0337 / 0.0600$ ) and it rose to explain 83 percent of inequality in 1996. The difference in the within group inequality over time was 1.14 of the difference in the overall inequality over time. Hence the share explained by between group inequality was -0.14 of the difference in overall inequality.

The three categories for which the between group inequality is relatively more important are the third (mentioned above), seventh (age of adults with number of adults and number of children) and eighth (if children present and number of economically active members) categories in Table 8. Here the differences in the means (not shown) of

\footnotetext{
${ }^{14}$ This is the finding in almost all decompositions of this sort - within group inequality is more important than between group inequality in explaining overall inequality.
} 
each group are relatively larger in explaining overall inequality than the dispersion of income within each group, as compared to the other five categories. Nevertheless, the pattern of greater increase in within group inequality than between group over time still holds.

The analysis of the impact on income inequality of demographic changes in the populations over the 1988 to 1996 period are presented in Table 9. The decomposition in Table 9 yields information on the impact that changes in the following four factors have on changes in overall inequality over time: i) changes in within group inequality (Term A); ii) changes in population shares on the within group component of inequality (Term B); iii) changes in population shares on the between group component of inequality (Term C); and iv) changes in the subgroup mean (Term D). The values in Table 9 are expressed as proportions (or shares) of the total difference in overall inequality. As was learned from the analysis in Table 8, the vast majority of the change in overall inequality in 1988 compared to 1996 was brought about the changes in inequality within each sub-group (e.g., the households with no, one, two or three plus children). In all but two groups -- number of children and economic activity of head of household -- the within group inequality (Term A) grew by more than 100 percent of the change in overall inequality. In all but one group (number of children) the change in the relative subgroup means (Term D) actually lowered the change in overall inequality. Hence, the dispersion within each group grew, but the differences in the relative means of these subgroups fell.

What about the shift in population shares (Terms B and C)? In general they increase inequality but their impact is small compared to the impact of Terms A and D. 
Moreover, they tend to impact between-group inequality more than within-group inequality. For example, the shift in the population shares of households headed by economically active individuals, pensioners and "other " (e.g., unemployed) increased between group inequality by a larger amount than it impacted within group inequality. Similarly, shifts in the share of the population across categories of "age of pensioner head" increased between group inequality but lowered within group inequality. In sum shifts in the demographic composition of the households are increasing overall inequality over time.

\section{Conclusions}

We have found a large increase in total income inequality in Slovakia eight years after the beginning of transition. The Gini index of household per capita income (net monetary income plus in-kind income) rose from 0.195 in 1988 to 0.263 in 1996. Using the LIS equivalent household income, the Gini rose from 0.187 to 0.250 . In this paper we examine the impact of markets and countervailing government safety nets on this change in inequality over time by analyzing shifts in sources of income, in their distributions, means, shares, and in the percentage of persons with these incomes (based on person allocations). We learned that the earned non-agricultural income contributes most to overall income inequality in each year, due to its large income share and to how unequally it is distributed (Factor Gini). Moreover, in 1996 it accounted for much more of total inequality than it did in 1988 and hence is the single most important factor contributing to the large increase in overall income inequality between 1988 and 1996. The distribution of pension income mitigated overall inequality in both years, but less so 
in 1996, whereas the distribution of other social payments played a much larger role in reducing income inequality in 1996 than in 1988.

We show there are large shifts in the demographic composition of households over time: far fewer households with children, far more households headed by pensioners, increases in the number of one-person households and decreases in large (five person) households. We find that these shifts in the demographic composition of households are increasing overall inequality, by increasing between group inequality. Their impact is larger than that found for the U.K. by Jenkins (1995) and Mookherjee and Shorrocks (1982). Nevertheless, most of the change in inequality over time is accounted for by increase in within group inequality. And given our finding above, we are lead to believe that this is due to an increase in the dispersion of labor earnings over this period. Finally it is interesting to note that although dispersion of income within each group has grown significantly over time, the differences in the means of each group have actually decreased over time. Hence between group inequality has declined from 1988 to 1996. We conclude that over the first seven years of the transition labor market forces are driving changes in overall inequality in Slovakia to a much greater extent than changes in the Government's social safety net or in individual's decisions about household formation. 


\section{REFERENCES}

Atkinson, Anthony B. and John Micklewright (1992), Economic Transformation in Eastern Europe and the Distribution of Income, Cambridge University Press.

Buhmann, Brigitte, Lee Rainwater, Guenther Schmaus, and Timothy M. Smeeding (1992), "Equivalence Scales, Well-Being, Inequality, and Poverty: Sensitivity Estimates Across Ten Countries Using the Luxembourg Income Study (LIS) Database," Review of Income and Wealth, Vol. 34., No. 2, June: 115-142.

Chase, Robert (1998), "Baby Boom or Bust? Changing Fertility in Post-Communist Czech Republic and Slovakia" William Davidson Institute Working Paper No. 157

Commission of the European Communities (CEC, 1992), Employment Observatory, Central and Eastern Europe, Employment Trends and Developments, No. 1, January.

Garner, Thesia I. and Katherine Terrell (1998), "A Gini Decompositon Analysis of Inequality in the Czech and Slovak Republics During the Transition," The Economics of Transition, 6(1): 23-46.

Jenkins, Stephen P. (1991), "The Measurement of Income Inequality" in Lars Osberg (ed.) Economic Inequality and Poverty: International Perspectives. Sharp Publishers: London: 3-38.

Jenkins, Stephen P. (1995), "Accounting for Inequality Trends: Decomposition Analyses for the U.K., 1971-86," Economica. 62(245): pp. 29-63.

Lambert, Peter J. (1993), The Distribution and Redistribution of Income, A Mathematical Analysis, Manchester, UK: Manchester University Press.

Lerman R. (1999), "How income sources affect income inequality?" in J.Silber (ed), Handbook on Income Inequality Measurement, Dordrecht: Kluwer Academic Publishers.

Lerman, Robert I. and Shlomo Yitzhaki (1985), "Income Inequality Effects by Income Sources: A New Approach and Applications to the U.S.," Review of Economics and Statistics, February, Vol. 67: 151-156.

Lerman, Robert I. and Shlomo Yitzhaki (1989), "Improving the Accuracy of Estimates of Gini Coefficients," Journal of Econometrics, September, Vol. 42: 43-47.

Lerman, Robert I. and Shlomo Yitzhaki (1994), "The Effect of Marginal Changes in Income Sources on U. S. Income Inequality," Public Finance Quarterly, October. 
Milanovic, Branko (1992), "Income Distribution in Late Socialism: Poland, Hungary, Czechoslovakia, Yugoslavia, and Bulgaria Compared," Socialist Economies Reform Unit, Country Economics Department, World Bank, Research paper series, paper number 1, March.

Milanovic, Branko (June 1992), "Distributional Impact of Cash and In-Kind Transfers in Eastern Europe and Czechoslovakia," Socialist Economies Reform Unit, Country Economics Department, World Bank, Research paper series, paper number 9.

Mookherjee, D. and A. F. Shorrocks (1982), "A decomposition analysis of the trend in UK income inequality,” Economic Journal, 92, 886-992.

Podder, Nripesh (1993), "The Disaggregation of the Gini Coefficient by Factor Components and its Applications to Australia," Review of Income and Wealth, Series 39, No. 1, March: 51-61

Shorrocks, A. F. (1984), "Inequality Decomposition by Population Subgroups," Econometrica, Vol. 52, No. 6: 1369-1385.

Shorrocks, A. F. (1980), "The Class of Additively Decomposable Inequality Measures," Econometrica, Vol. 48, No. 3: 613-625.

Slovak Central Statistical Office (2001), website: http://www.statistics.sk/.

Smeeding, Timothy M. (1991), "Cross-National Comparisons of Inequality and Poverty Position," in Lars Osberg (ed.), Economic Inequality and Poverty: International Perspectives, New York: M. E. Sharpe, Inc., pp. 39-59.

Tsakloglou P. (1993) "Aspects of inequality in Greece: Measurement, decomposition and inter-temporal change: 1974, 1982," Journal of Development Economics, 40: 5374.

Yitzhaki, Shlomo (1989), "Ginjack and Ginjackw," Fortran program, September 27 
Table 1

Macroeconomic Data for Slovakia

\begin{tabular}{|c|c|c|c|c|c|c|c|c|c|c|c|}
\hline \multirow[b]{2}{*}{ Economic Growth } & 1990 & 1991 & 1992 & 1993 & 1994 & 1995 & 1996 & 1997 & 1998 & 1999 & \multirow[b]{2}{*}{ Source } \\
\hline & & & & & & & & & & & \\
\hline$\overline{\% G D P ~ g r o w t h ~(r e a l) ~}$ & -2.5 & -14.6 & -6.5 & -3.7 & 4.9 & 6.7 & 6.2 & 6.2 & 4.1 & 1.9 & $\overline{\text { EBRD, }}$ EIU \\
\hline GDP per capita (\$US) & 2,710 & 2,052 & 2,213 & 2,258 & 2,571 & 3,240 & 3,495 & 3,679 & 3,802 & 3,970 & EBRD, OECD \\
\hline \multicolumn{12}{|l|}{ Prices } \\
\hline 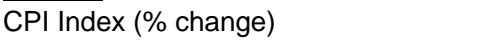 & 18.4 & 58.3 & 9.1 & 25.1 & 11.7 & 7.2 & 5.4 & 6.4 & 5.6 & 14.0 & World Bank, EBRD, DataStream \\
\hline \multicolumn{12}{|l|}{ Trade } \\
\hline Current Account Balance (\%GDP) & -6.1 & 3 & 1.6 & -5 & 4.8 & 2.3 & -11.2 & -10 & -10.1 & -5.5 & World Bank, EBRD, EIU \\
\hline Market Liberlization & & & & & & & & & & & \\
\hline Private Sector Share of GDP (\%) & 5 & NA & NA & NA & 55 & 60 & 70 & 75 & 75 & 75 & World Bank, EBRD \\
\hline Labor Markets & & & & & & & & & & & \\
\hline Unemployment Rate (\%) & 1.5 & 11.8 & 10.3 & 12.2 & 13.7 & 13.1 & 11.1 & 11.6 & 11.9 & 19.2 & EBRD, Business Central Europe \\
\hline$\%$ change in productivity & NA & NA & NA & NA & 6.8 & 4.0 & 2.5 & 4.1 & 11.5 & 2.0 & EBRD \\
\hline$\%$ change in wages & NA & NA & NA & NA & 7.0 & 5.7 & 9.8 & 7.5 & 6.1 & -3.9 & EBRD \\
\hline Index of Employment Levels $(1989=1)^{\star}$ & 0.982 & 0.859 & 0.868 & 0.846 & 0.837 & 0.857 & 0.845 & 0.826 & 0.818 & 0.780 & UNDP \\
\hline
\end{tabular}

*Employment in 1989 was 2,504,079 
Table 2

Slovakia: Population Changes in Rates per 1,000 Inhabitants

\begin{tabular}{l|r|r|r|r|r|r|r|r}
\hline Indicator & 1989 & 1990 & 1991 & 1992 & 1993 & 1994 & 1995 & 1996 \\
\hline Marriages & 6.90 & 7.60 & 6.20 & 6.40 & 5.80 & 5.30 & 5.10 & 5.10 \\
Divorces & 1.57 & 1.67 & 1.49 & 1.52 & 1.53 & 1.62 & 1.67 & 1.75 \\
Live-Births & 15.20 & 15.10 & 14.90 & 14.10 & 13.80 & 12.40 & 11.40 & 11.20 \\
Deaths & 10.20 & 10.30 & 10.30 & 10.10 & 9.90 & 9.60 & 9.80 & 9.50 \\
Infant Mortality & 13.50 & 12.00 & 13.20 & 12.60 & 10.60 & 11.20 & 11.00 & 11.00 \\
Natural Increase & 5.00 & 4.80 & 4.60 & 4.00 & 3.90 & 2.80 & 1.60 & 1.70 \\
\hline
\end{tabular}

Source: Statistical Yearbook of the Slovak Republic, 1996 (p. 154) 
Table 3

Slovakia: Overall Income Inequality: 1988 and $1996^{1}$

\begin{tabular}{l|c|c|c|c|c|c|c|c|c}
\hline & \multicolumn{3}{|c|}{$\begin{array}{c}1988 \\
(n=31,606)\end{array}$} & \multicolumn{3}{c|}{$\begin{array}{c}1996 \\
(n=16,336)\end{array}$} & \multicolumn{3}{c}{ \% difference (1996 vs.1988) } \\
\cline { 2 - 10 } & OECD & LIS & PC & OECD & LIS & PC & OECD & LIS & PC \\
\hline Log Deviation & 0.050 & 0.062 & 0.062 & 0.125 & 0.128 & 0.142 & 150.1 & 107.2 & 129.3 \\
Thiel & 0.051 & 0.060 & 0.065 & 0.111 & 0.112 & 0.128 & 117.6 & 86.7 & 96.9 \\
CV2/2 & 0.060 & 0.067 & 0.079 & 0.134 & 0.131 & 0.157 & 123.8 & 96.1 & 99.2 \\
Gini & 0.172 & 0.187 & 0.195 & 0.243 & 0.25 & 0.263 & 41.3 & 33.7 & 34.9 \\
\hline
\end{tabular}

Data: Slovak Republic Microcensus 1988 and 1996

${ }^{1}$ Household equivalent after tax monetary plus in-kind income, LIS equivalence scale; person weighted distribution 
Table 4

Slovakia: Income Distribution ${ }^{1}$ by Source within Each Decile

\section{$\underline{1988}$}

\begin{tabular}{|c|c|c|c|c|c|c|c|}
\hline \multirow[b]{2}{*}{ Decile } & \multicolumn{2}{|c|}{ Earned Income } & \multicolumn{2}{|c|}{ Social Payments } & \multirow{2}{*}{$\begin{array}{c}\text { Other monetary } \\
\text { income }\end{array}$} & \multirow{2}{*}{$\begin{array}{l}\text { In-Kind } \\
\text { Income }\end{array}$} & \multirow[b]{2}{*}{ Total } \\
\hline & Non-Agricultural & Agricultural & Pension & Excluding pension & & & \\
\hline 1 & $23.5 \%$ & $1.7 \%$ & $58.1 \%$ & $11.3 \%$ & $2.1 \%$ & $3.4 \%$ & $100.0 \%$ \\
\hline 2 & $48.6 \%$ & $3.6 \%$ & $24.6 \%$ & $18.3 \%$ & $1.8 \%$ & $3.1 \%$ & $100.0 \%$ \\
\hline 3 & $59.1 \%$ & $4.6 \%$ & $14.1 \%$ & $18.0 \%$ & $1.3 \%$ & $2.7 \%$ & $100.0 \%$ \\
\hline 4 & $65.6 \%$ & $4.8 \%$ & $10.0 \%$ & $16.1 \%$ & $0.8 \%$ & $2.6 \%$ & $100.0 \%$ \\
\hline 5 & $68.0 \%$ & $6.0 \%$ & $8.3 \%$ & $14.0 \%$ & $0.9 \%$ & $2.8 \%$ & $100.0 \%$ \\
\hline 6 & $68.0 \%$ & $7.5 \%$ & $8.1 \%$ & $12.1 \%$ & $0.8 \%$ & $3.4 \%$ & $100.0 \%$ \\
\hline 7 & $67.1 \%$ & $9.3 \%$ & $8.6 \%$ & $10.3 \%$ & $0.9 \%$ & $3.7 \%$ & $100.0 \%$ \\
\hline 8 & $66.9 \%$ & $10.3 \%$ & $9.0 \%$ & $8.5 \%$ & $0.9 \%$ & $4.4 \%$ & $100.0 \%$ \\
\hline 9 & $66.2 \%$ & $12.2 \%$ & $8.7 \%$ & $7.2 \%$ & $1.0 \%$ & $4.6 \%$ & $100.0 \%$ \\
\hline 10 & $61.5 \%$ & $18.8 \%$ & $7.6 \%$ & $5.4 \%$ & $1.4 \%$ & $5.3 \%$ & $100.0 \%$ \\
\hline
\end{tabular}

\section{$\underline{1996}$}

\begin{tabular}{|c|c|c|c|c|c|c|c|}
\hline \multirow[b]{2}{*}{ Decile } & \multicolumn{2}{|c|}{ Earned Income } & \multicolumn{2}{|c|}{ Social Payments } & \multirow{2}{*}{$\begin{array}{c}\text { Other monetary } \\
\text { income }\end{array}$} & \multirow{2}{*}{$\begin{array}{l}\text { In-Kind } \\
\text { Income }\end{array}$} & \multirow[b]{2}{*}{ Total } \\
\hline & Non-Agricultural & Agricultural & Pension & Excluding pension & & & \\
\hline 1 & $32.7 \%$ & $0.7 \%$ & $30.9 \%$ & $31.4 \%$ & $1.5 \%$ & $2.9 \%$ & $100.0 \%$ \\
\hline 2 & $39.8 \%$ & $0.9 \%$ & $36.2 \%$ & $20.1 \%$ & $1.3 \%$ & $1.7 \%$ & $100.0 \%$ \\
\hline 3 & $46.7 \%$ & $1.1 \%$ & $33.2 \%$ & $16.1 \%$ & $1.0 \%$ & $1.9 \%$ & $100.0 \%$ \\
\hline 4 & $50.8 \%$ & $1.2 \%$ & $32.2 \%$ & $12.5 \%$ & $1.2 \%$ & $2.0 \%$ & $100.0 \%$ \\
\hline 5 & $57.9 \%$ & $0.8 \%$ & $26.9 \%$ & $11.1 \%$ & $0.9 \%$ & $2.4 \%$ & $100.0 \%$ \\
\hline 6 & $65.6 \%$ & $1.8 \%$ & $20.1 \%$ & $8.7 \%$ & $1.2 \%$ & $2.6 \%$ & $100.0 \%$ \\
\hline 7 & $73.4 \%$ & $1.5 \%$ & $14.6 \%$ & $6.9 \%$ & $1.2 \%$ & $2.3 \%$ & $100.0 \%$ \\
\hline 8 & $76.8 \%$ & $1.5 \%$ & $12.5 \%$ & $5.0 \%$ & $1.6 \%$ & $2.6 \%$ & $100.0 \%$ \\
\hline 9 & $77.9 \%$ & $1.8 \%$ & $11.5 \%$ & $3.6 \%$ & $2.5 \%$ & $2.6 \%$ & $100.0 \%$ \\
\hline 10 & $85.5 \%$ & $1.1 \%$ & $4.5 \%$ & $1.5 \%$ & $6.0 \%$ & $1.4 \%$ & $100.0 \%$ \\
\hline
\end{tabular}




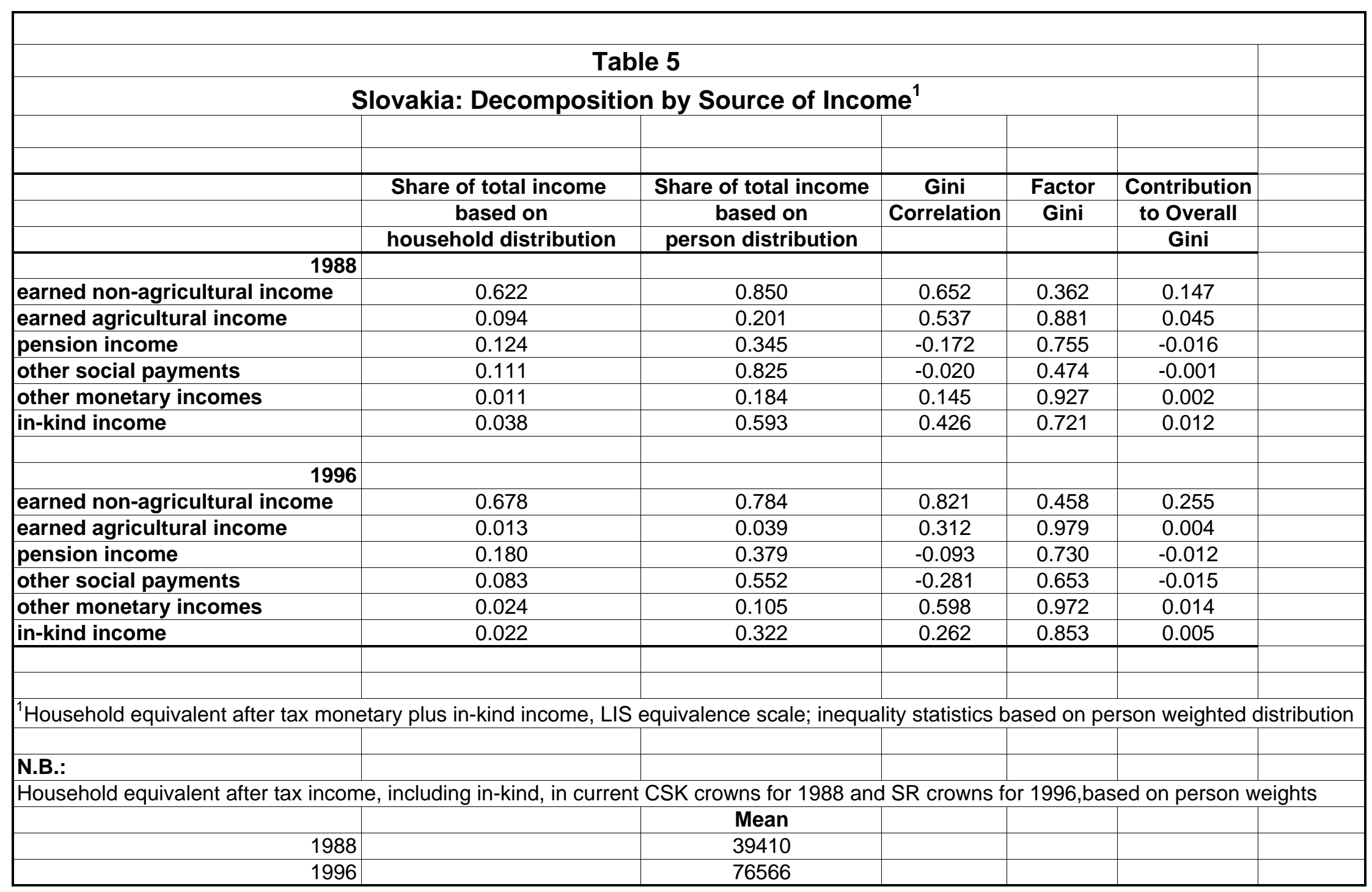


Table 6 Slovakia: Demographic Composition of the Household (Percentage Distribution of Households)

\begin{tabular}{|c|c|c|c|c|c|}
\hline Charactersitic & 1988 & 1996 & Charactersitic & 1988 & 1996 \\
\hline Children Present in Household & & & Age of Head & & \\
\hline no children & 55.4 & 67.0 & head $<=29$ years of age & 10.1 & 5.9 \\
\hline \multirow[t]{2}{*}{ children present } & 44.6 & 33.0 & head $30-34$ years of age & 11.9 & 7.0 \\
\hline & & & head 35-39 years of age & 12.5 & 9.4 \\
\hline Number of Children & & & head $40-44$ years of age & 10.6 & 13.0 \\
\hline no children & 55.4 & 67.0 & head $45-49$ years of age & 9.2 & 13.4 \\
\hline one child & 16.8 & 16.4 & head $50-54$ years of age & 8.6 & 10.3 \\
\hline two children & 19.7 & 12.9 & head $55-59$ years of age & 9.2 & 8.7 \\
\hline \multirow[t]{2}{*}{ three or more children } & 8.1 & 3.7 & head $60-64$ years of age & 8.6 & 8.3 \\
\hline & & & head $65-69$ years of age & 8.0 & 8.1 \\
\hline Economic Activity of Head & & & head $70+$ years of age & 11.3 & 14.8 \\
\hline economically active & 73.3 & 60.4 & missing & & 1.1 \\
\hline unemployed & none & 3.5 & & & \\
\hline pensioner & 26.4 & 34.7 & Age of Pensioner Head & & \\
\hline \multirow[t]{2}{*}{ other } & 0.3 & 1.4 & no pensioners & 72.7 & 65.3 \\
\hline & & & pensioner head $<=59$ years of age & 4.4 & 5.2 \\
\hline Household Size & & & pensioner head $60-64$ years of age & 5.9 & 6.9 \\
\hline one person & 17.8 & 21.2 & pensioner head $65-69$ years of age & 6.7 & 7.9 \\
\hline two persons & 24.3 & 23.0 & pensioner head $70+y e a r s$ of age & 10.3 & 14.8 \\
\hline three persons & 17.6 & 17.7 & & & \\
\hline four persons & 24.1 & 25.4 & No. of Econ. Active Members & & \\
\hline five persons & 10.9 & 8.7 & no econ active members & 21.5 & 28.2 \\
\hline \multirow[t]{3}{*}{ six or more persons } & 5.3 & 4.0 & one econ active member & 25.0 & 26.6 \\
\hline & & & two econ active members & 42.0 & 33.9 \\
\hline & & & 3 or more econ active members & 11.5 & 11.3 \\
\hline
\end{tabular}




\section{Table7}

Slovakia: Number of Pensioners and Average Monthly Pension, ${ }^{1} 1989-$ 1995

\begin{tabular}{|c|c|c|c|c|c|c|c|}
\hline & 1989 & 1990 & 1991 & 1992 & 1903 & 1091 & \\
\hline Total & 1065 & 1087 & 1124 & 1156 & 1172 & 1178 & 1173 \\
\hline Old-Age & 488 & 506 & 532 & 548 & 553 & 556 & 558 \\
\hline Disability $^{2 \star}$ & 218 & 223 & 230 & 243 & 252 & 256 & 248 \\
\hline Widow & 270 & 275 & 279 & 283 & 286 & 288 & 291 \\
\hline
\end{tabular}

\section{Average Monthly Pension (in Slovak crowns)}

\begin{tabular}{c|c|c|c|c|c|c|c}
\hline & $\mathbf{1 9 8 9}$ & $\mathbf{1 9 9 0}$ & $\mathbf{1 9 9 1}$ & $\mathbf{1 9 9 2}$ & $\mathbf{1 9 9 3}$ & $\mathbf{1 9 9 4}$ & $\mathbf{1 9 9 5}$ \\
\hline Old-Age & 1432 & 1550 & 1884 & 2058 & 2367 & 2852 & 3102 \\
Disability & 1310 & 1413 & 1750 & 1940 & 2247 & 2714 & 2950 \\
Widow & 742 & 825 & 1007 & 1118 & 1255 & 1431 & 1594 \\
\hline
\end{tabular}

Average Pension as a Share of the Wage

\begin{tabular}{c|c|c|c|c|c|c|c}
\hline & 1989 & 1990 & 1991 & 1992 & 1993 & 1994 & 1995 \\
\hline Old-Age & $46.3 \%$ & $48.2 \%$ & $50.3 \%$ & $45.5 \%$ & $45.0 \%$ & $46.8 \%$ & $43.8 \%$ \\
Disability & $42.4 \%$ & $43.9 \%$ & $46.7 \%$ & $42.9 \%$ & $42.7 \%$ & $44.6 \%$ & $41.7 \%$ \\
Widow & $24.0 \%$ & $25.6 \%$ & $26.9 \%$ & $24.7 \%$ & $23.9 \%$ & $23.5 \%$ & $22.5 \%$ \\
\hline
\end{tabular}

Source: Statistical Yearbook of the Slovak Republic, 1994 (p.148, 406) and 1996 (p.180, 476)

\footnotetext{
${ }^{1}$ Monthly level of pension paid out excluding child support bonus and disability benefits
}

${ }^{2}$ For the handicapped 
Table 8

Within-Group and Between-Group Income Inequality ${ }^{1}$ in Slovakia: 1988 and 1996

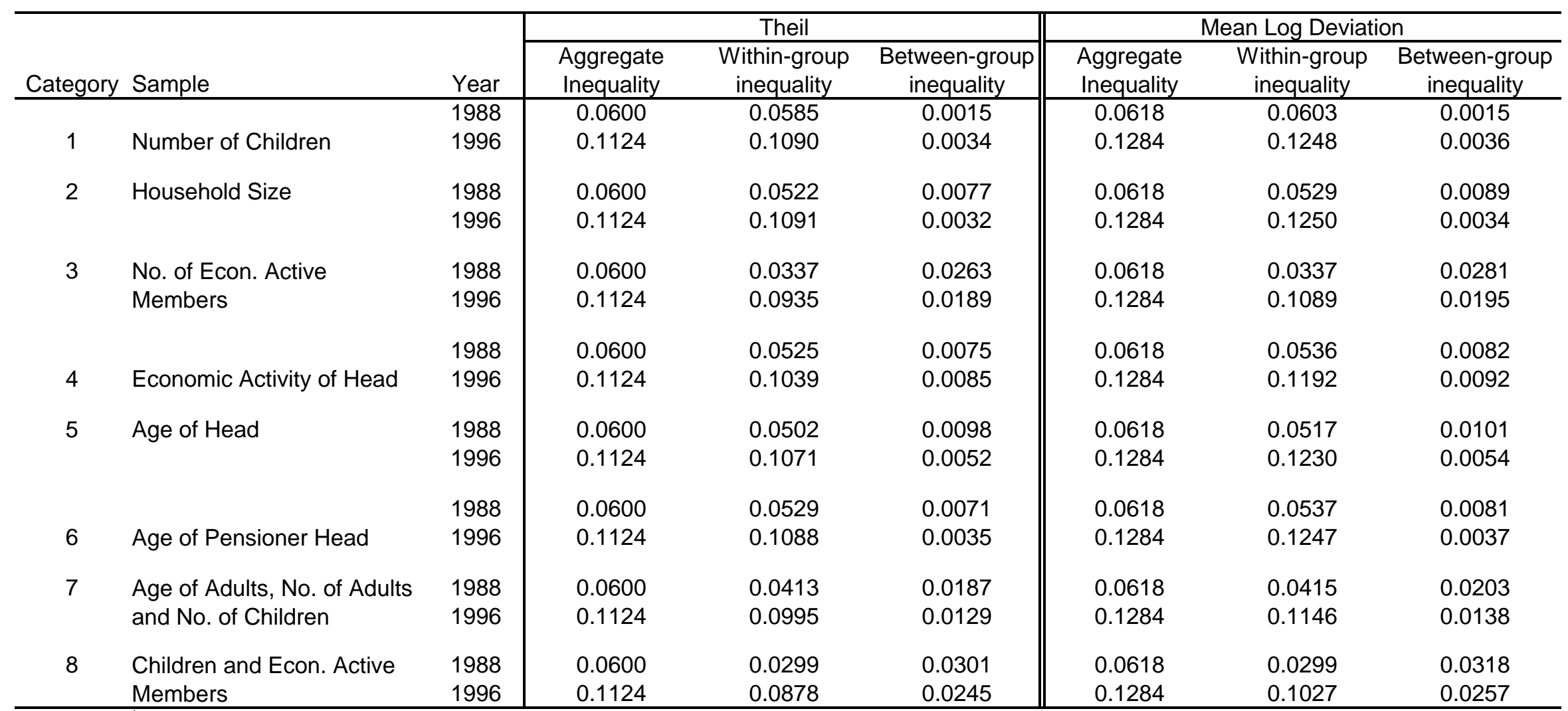

${ }^{1}$ Household equivalent after tax monetary plus in-kind income, LIS equivalence scale; person weighted distribution

Subgroup defined as follows:

Number of Children: no children, 1 child, two children, 3+ children

Number of $\mathrm{HH}$ Members: one, two three, four, five+

Number of economically active members: none, one, two, three+

Economic Activity of Head: economically active, pensioner, other

Age of Head: 15-39, 40-54, 55-64, 65+

Age of pensioner: no pensioner head, pensioner l.t. 65 , pensioner g.t. eq. 65 years.
Age I.t. 65, no children,two adults; 3) Age l.t. 65, no children, three+ adults; 4) Age l.t. 65, children, two adults; 5) Age l.t. 65, on child, two adults; 6) Age I.t. 65, two children, two adults; 7) Age I.t. 65, three+ children, two adults; 8) Age I.t. 65, children, three+ adults; 9) Age g.t. 65, with and without children, one adult 10) Age

Econ. Activity and no. of children: 1) no children, no econ active adult; 2) no children, one econ active adult; 3) no children, two econ active adults; 4) no children, three+ econ active adults; 5) children, no econ active adult; 6) children, one econ active adult; 7) children, two econ active adults; 8) children, three+ econ active adults. 


\section{Sub-group Decompositions of Changes in Aggregate Income Inequality: 1988 - $1996^{1}$}

\begin{tabular}{|c|c|c|c|c|}
\hline & \multicolumn{4}{|c|}{$\begin{array}{c}\text { Contribution to change in overall inequality due } \\
\text { to changes in: }\end{array}$} \\
\hline & $\begin{array}{l}\text { Within Group } \\
\text { inequality } \\
\text { (Term A) }\end{array}$ & $\begin{array}{r}\begin{array}{r}\text { Populati } \\
\text { effe }\end{array} \\
\text { within } \\
(\text { Term B) } \\
\end{array}$ & $\begin{array}{l}\text { on Shares } \\
\text { ct on } \\
\text { between } \\
(\text { Term C) }\end{array}$ & $\begin{array}{c}\text { Group } \\
\text { Mean } \\
\text { Incomes } \\
\text { (Term D) } \\
\end{array}$ \\
\hline No. Children & 0.889 & 0.087 & -0.022 & 0.046 \\
\hline Household Size & 1.067 & 0.013 & 0.015 & -0.095 \\
\hline No. Econ. Active Members & 1.127 & -0.007 & 0.099 & -0.218 \\
\hline Econ. Activity of Head & 0.928 & 0.046 & 0.128 & -0.102 \\
\hline Age of Pensioner Head & 1.061 & -0.009 & 0.047 & -0.100 \\
\hline No. Children, No. and Age of Adults & 1.089 & 0.009 & 0.026 & -0.125 \\
\hline Children-Econ Active Members & 1.077 & 0.005 & 0.139 & -0.221 \\
\hline
\end{tabular}

${ }^{1}$ Household equivalent after tax monetary plus in-kind income, LIS equivalence scale; person weighted distribution; Based on the Mean Log Deviation Measure of Inequality.

Subgroup defined as follows:

Number of Children: no children, 1 child, two children, 3+ children

Number of HH Members: one, two three, four, five+

Number of economically active members: none, one, two, three+

Economic Activity of Head: economically active, pensioner, other

Age of Head: 15-39, 40-54, 55-64, 65+

Age of pensioner: no pensioner head, pensioner l.t. 65 , pensioner g.t. eq. 65 years.

Age and No. of adults and no. of children: 1) Age I.t. 65, no children,one adult; 2) Age I.t. 65, no children,two adults; 3) Age l.t. 65, no children, three+ adults; 4) Age I.t. 65, children, two adults; 5) Age I.t. 65, on child, two adults; 6) Age I

Econ. Activity and no. of children: 1) no children, no econ active adult; 2) no children, one econ active adult; 3) no children, two econ active adults; 4) no children, three+ econ active adults; 5) children, no econ active adult; 6) children, one 


\section{Chart 1 \\ Lorenz Curve and Concentration Curve for All Income \\ Lorenz Curve: Total Household Income Including In-kind}

shares of total after tax household income including in-kind shares of income from working (earned)

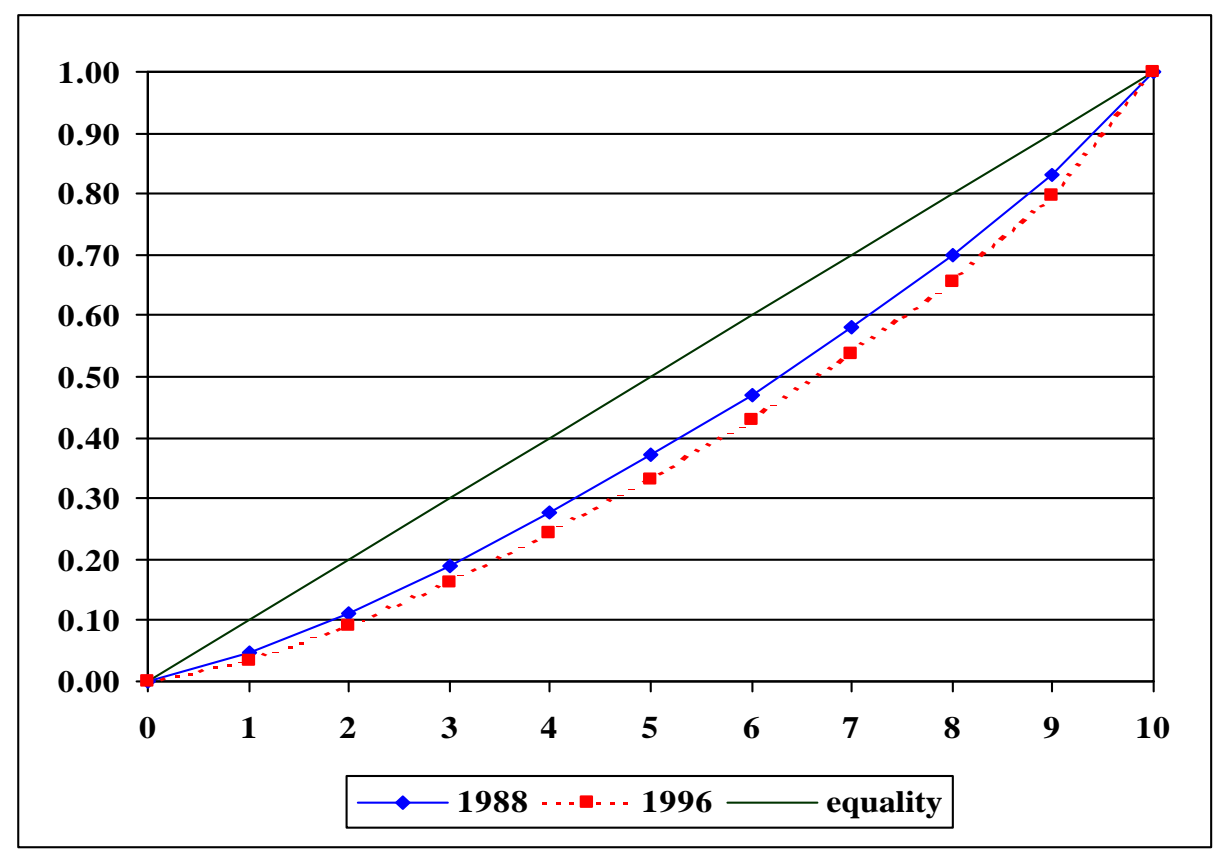

Deciles of persons ranked by equivalent total after tax household income including in-kind -LIS scale

\section{Concentration Curve: All Earned Income}

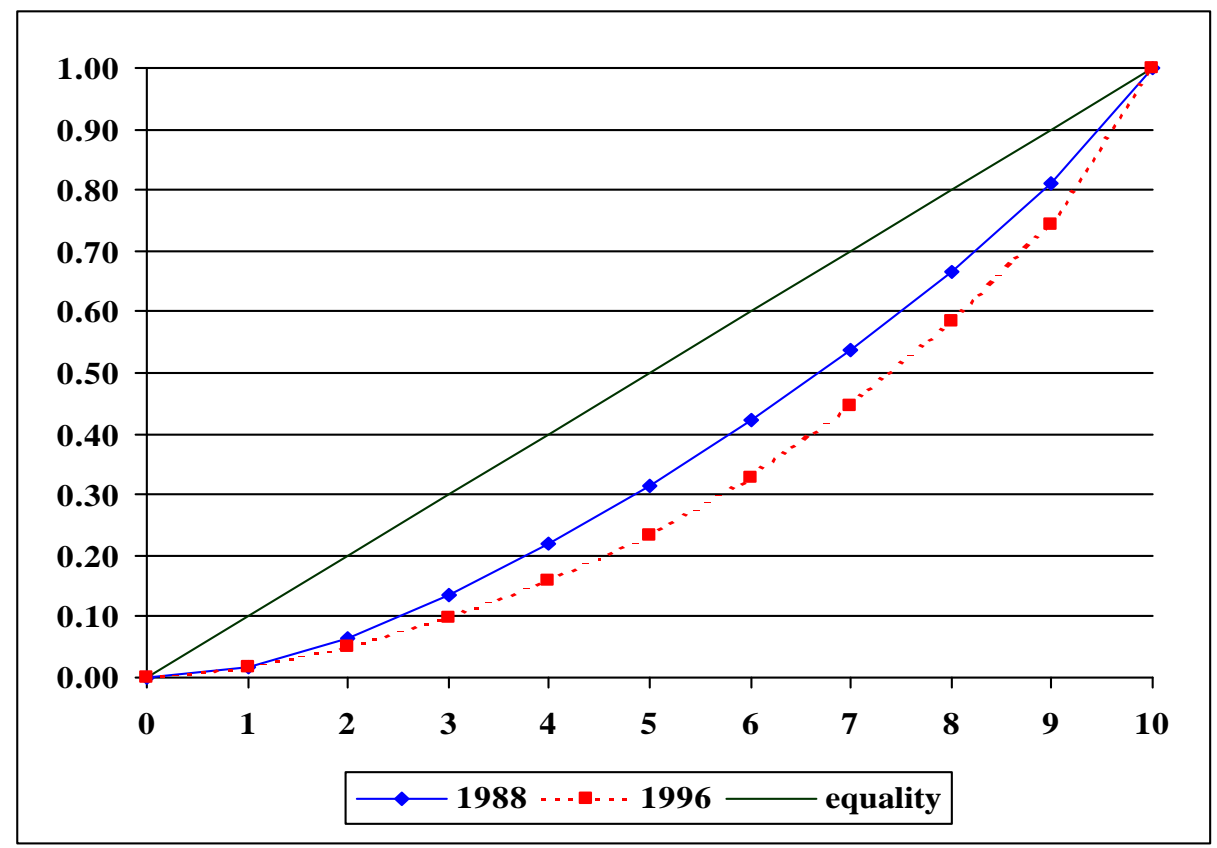

Deciles of persons ranked by equivalent total after tax household income including in-kind -LIS scale 
Chart 2

Concentration Curves: Non Agricultural vs. Agricultural Income Non-Agricultural Earned Income

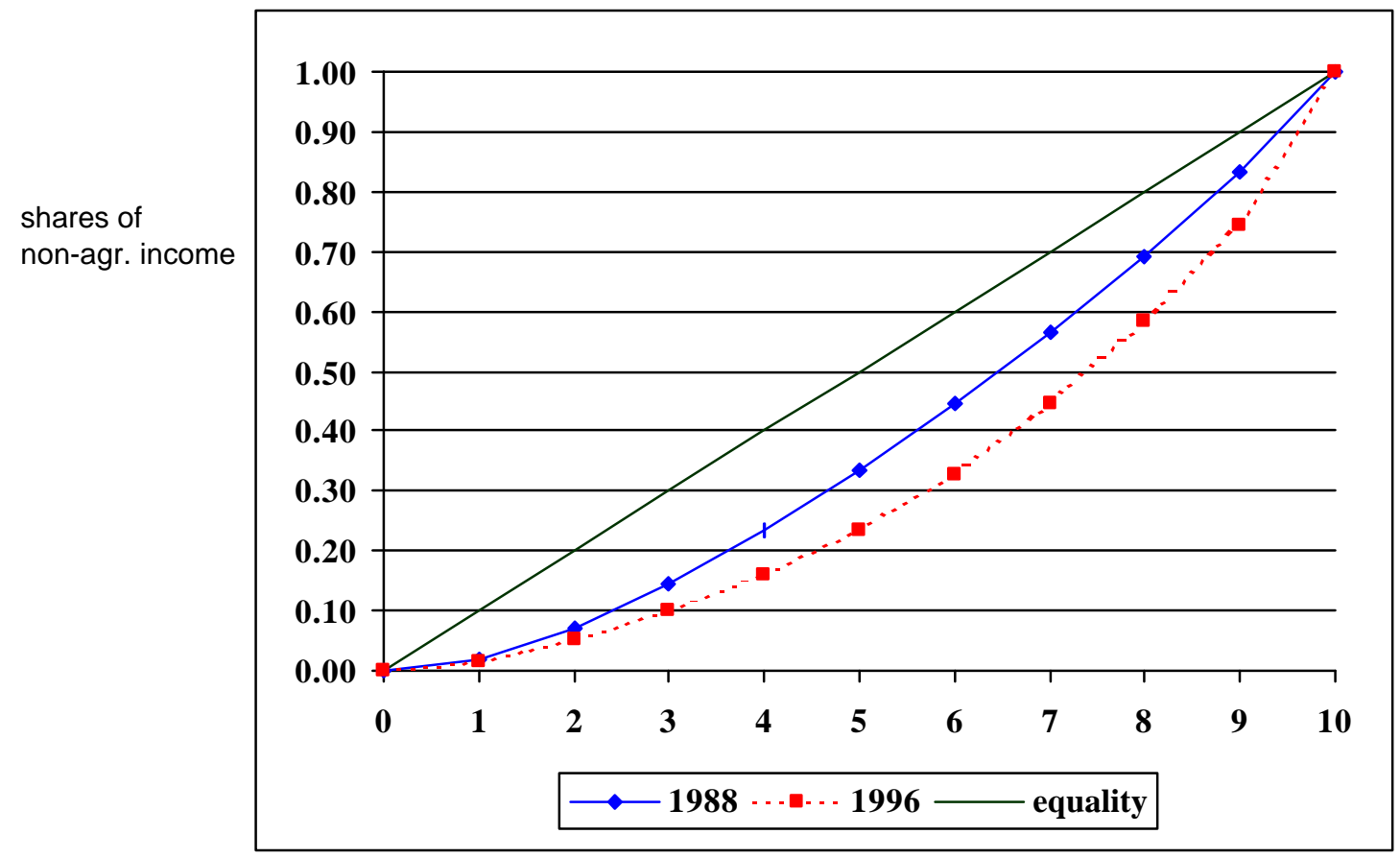

Deciles of persons ranked by equivalent total after tax household income including in-kind -LIS scale

\section{Earned Agricultural Income}

shares of agr. income

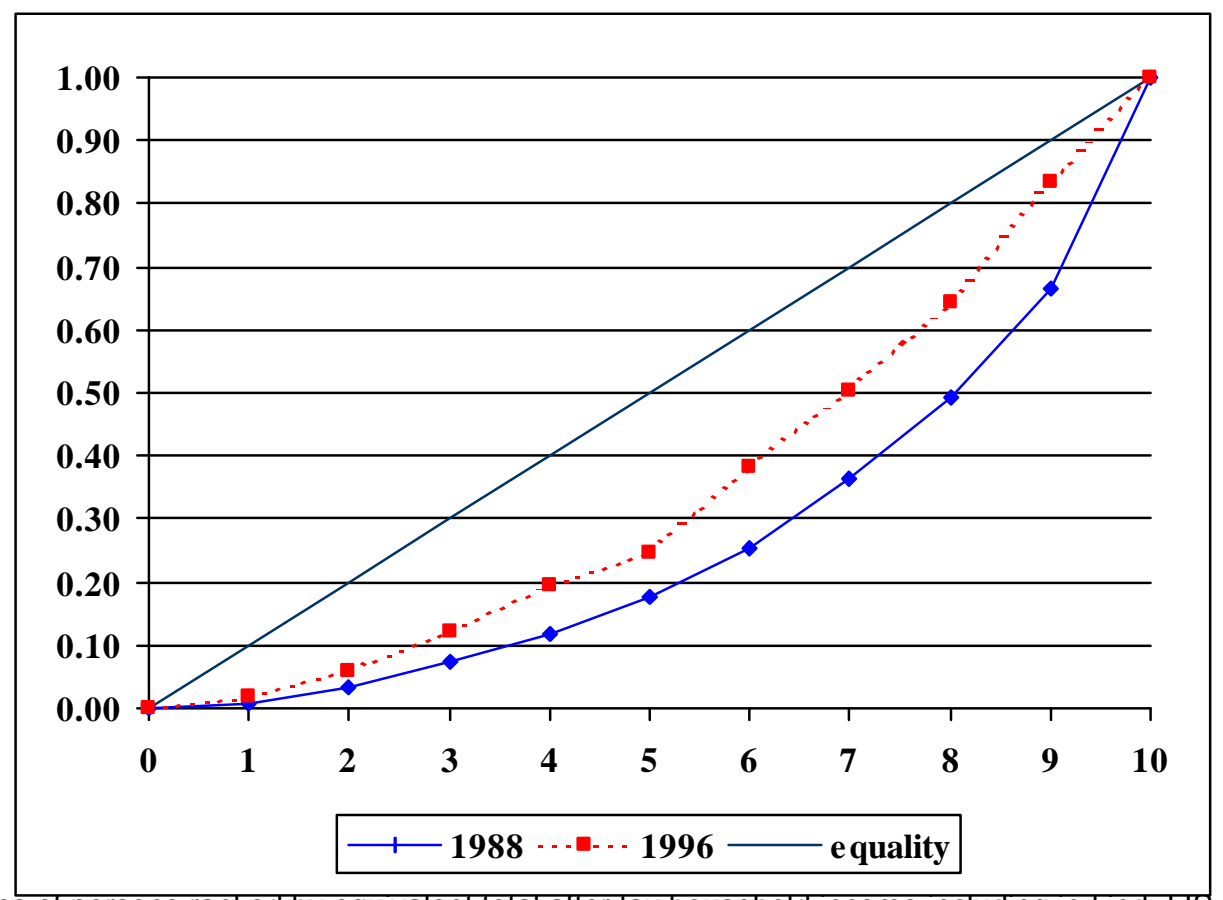

Deciles of persons ranked by equivalent total after tax household income Inclualng in-kInd -LIS scale 
Chart 3

Percentage of Households with Earned Income: Agricultural vs. Non-Agricultural
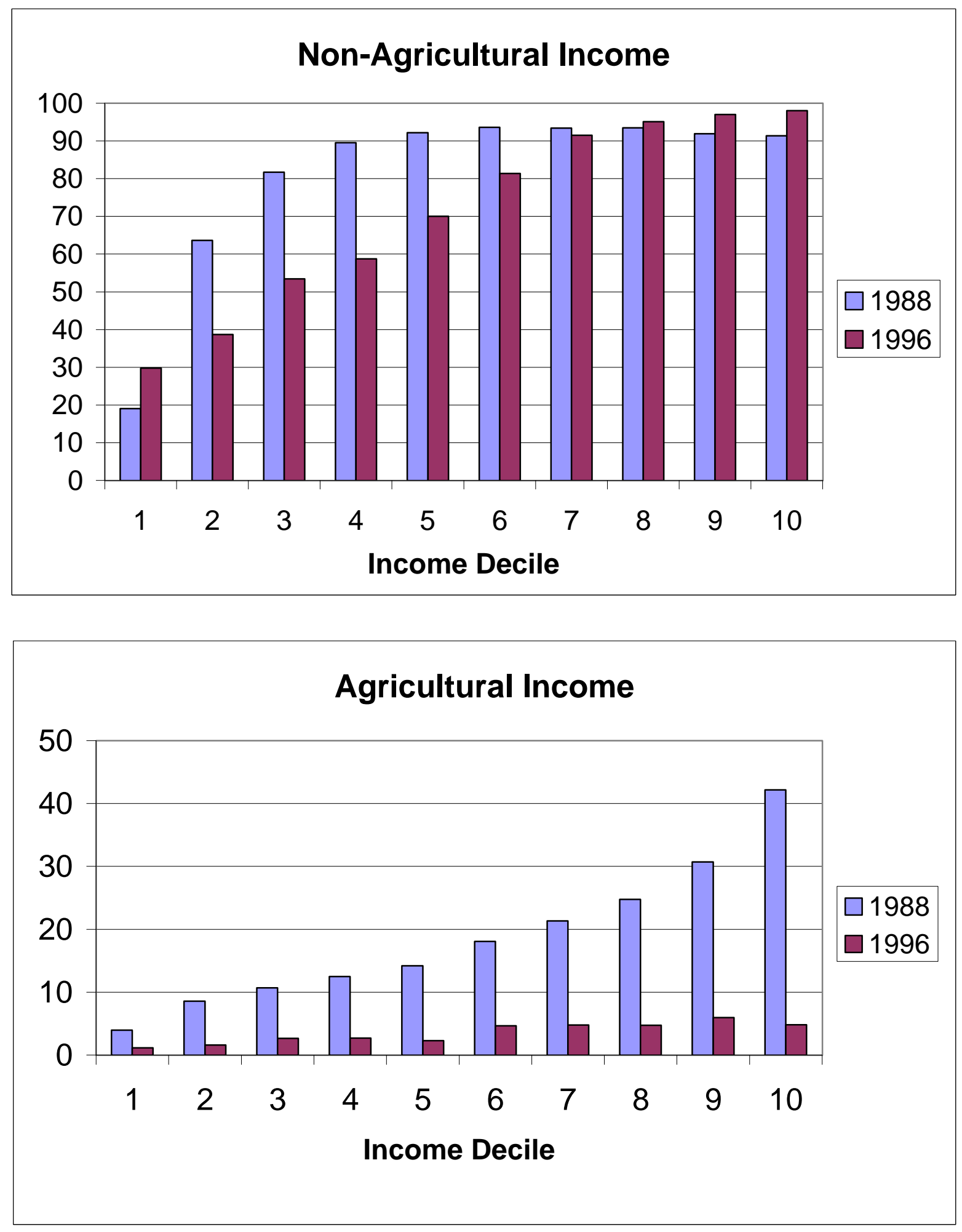


\section{Chart 4}

\section{Concentration Curves of Other Source of Income}

\section{Pension Income}

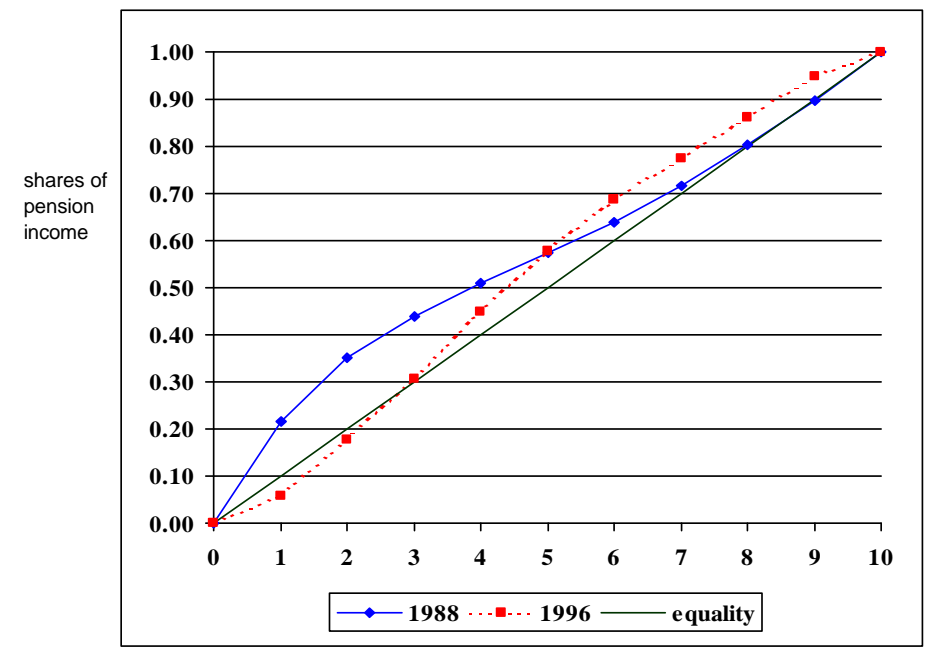

Other Net Monetary Income

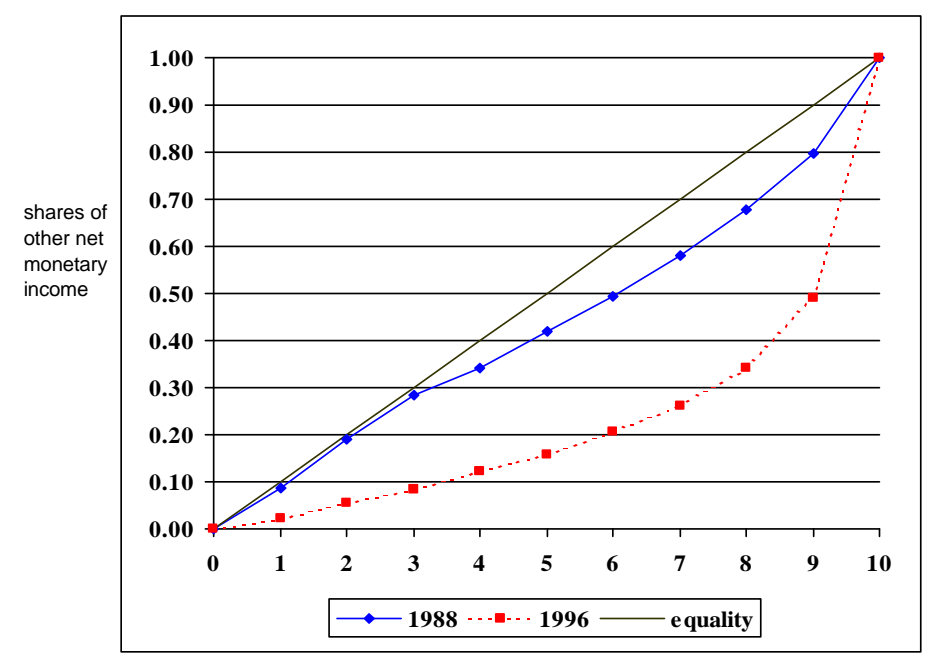

Social Income not including Pensions

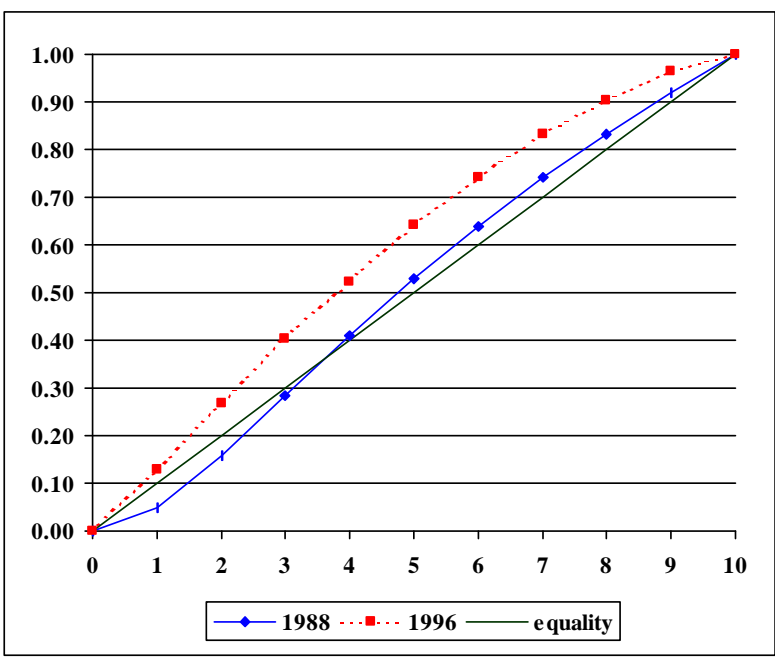

In-kind Income

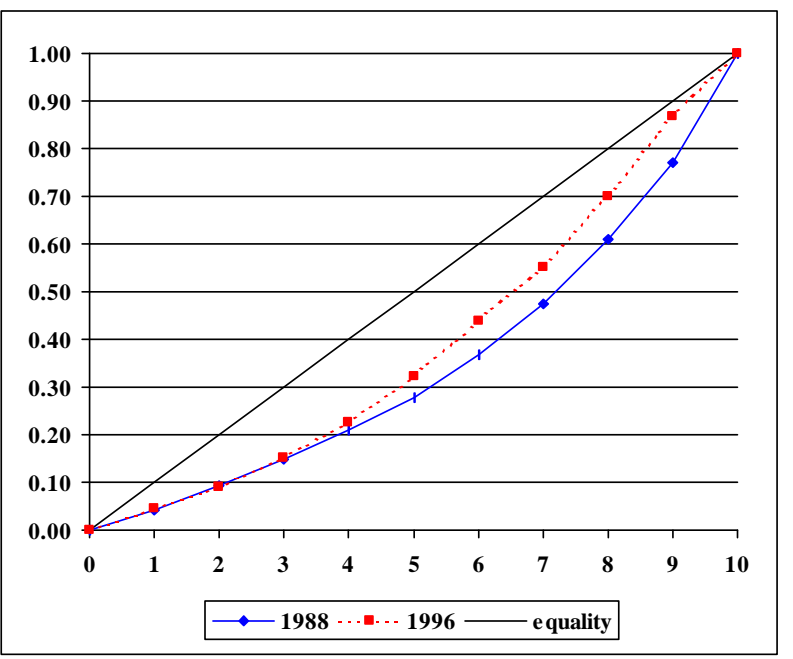




\section{Chart 5}

Percentage of Households with Unearned Income by Source
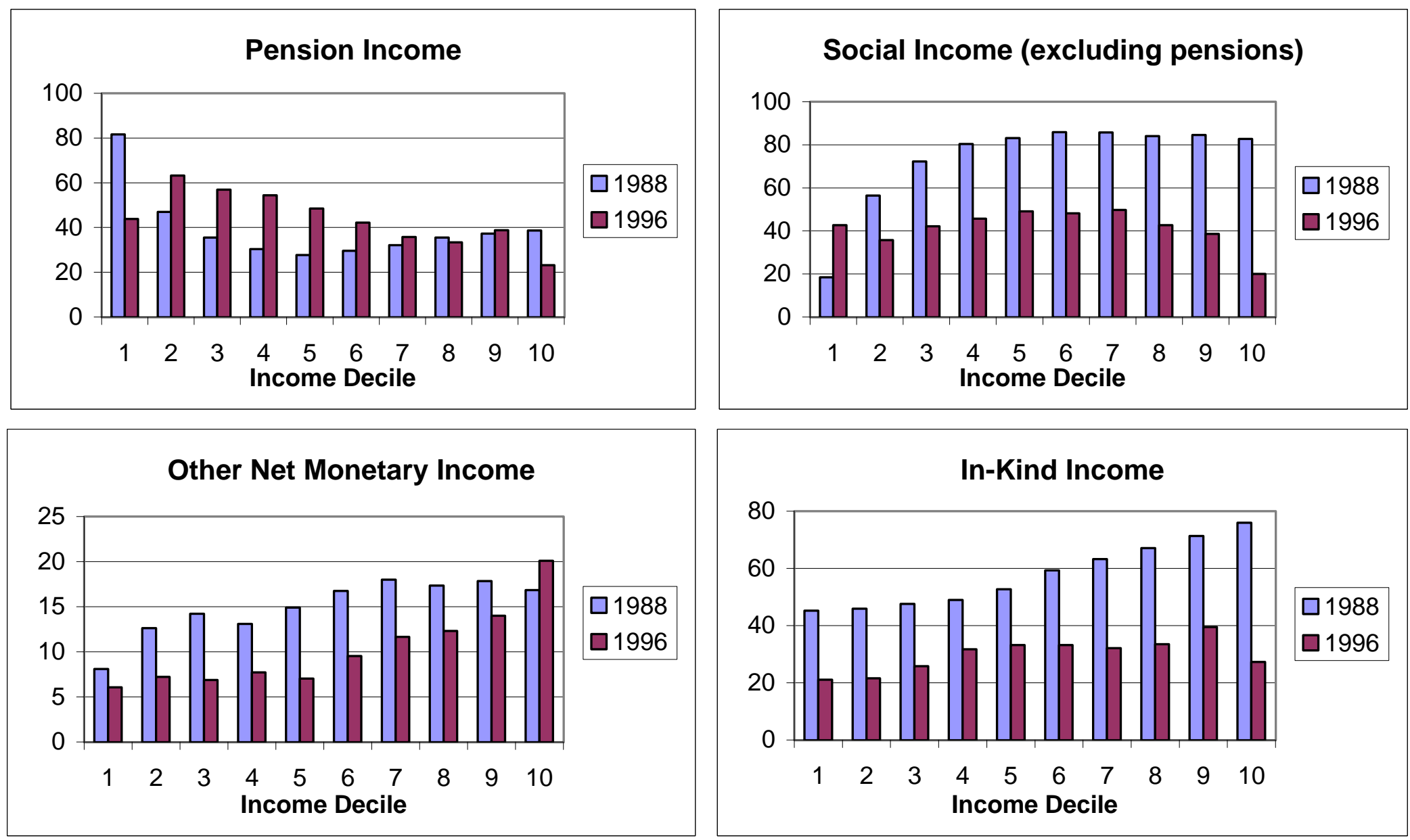
Chart 6

Demographic Characteristics by Income Decile
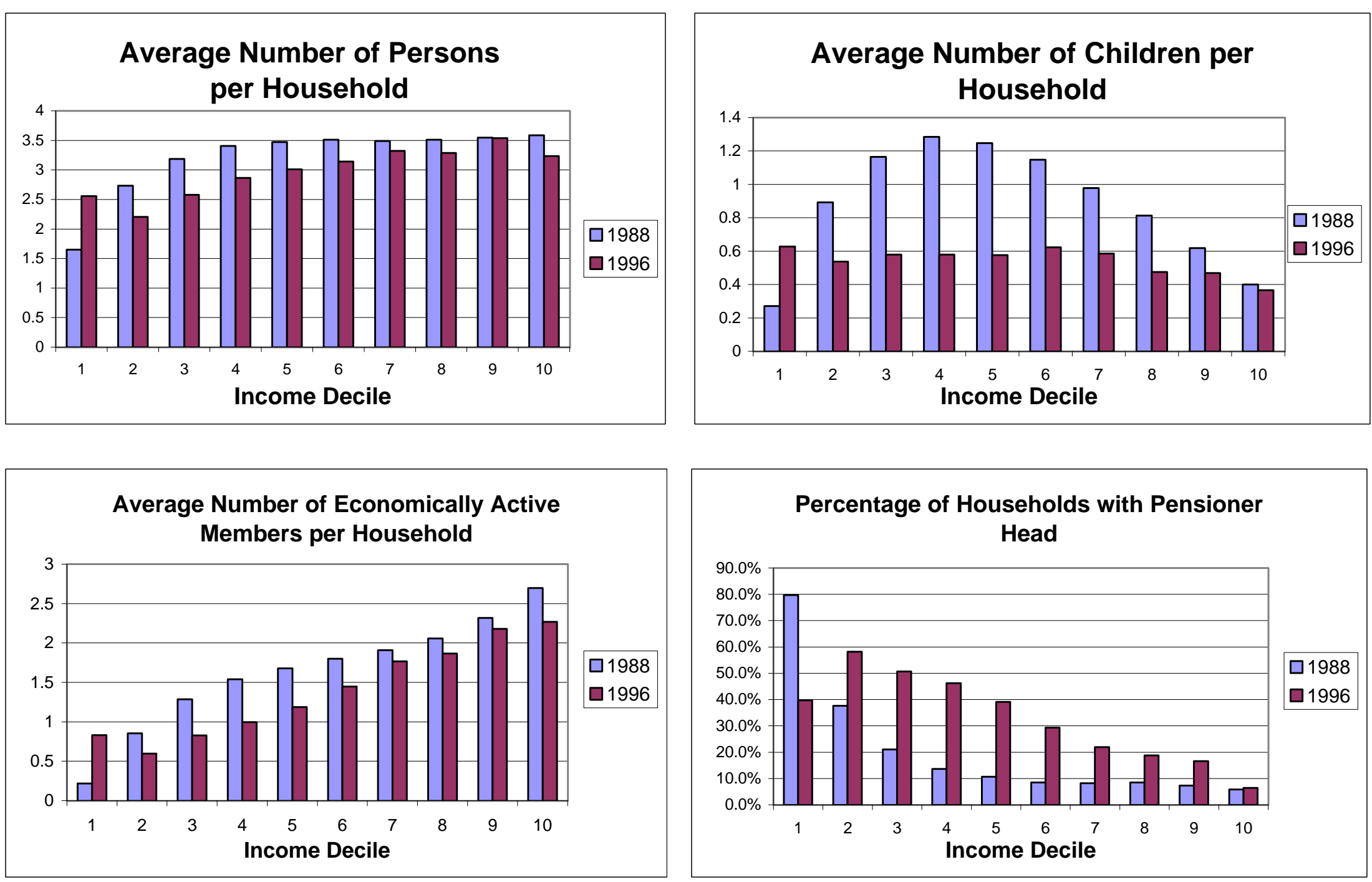


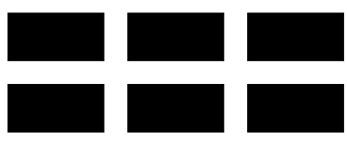

THE WILLIAM DAVIDSON INSTITUTE

AT THE UNIVERSITY OF MICHIGAN BUSINESSSCHOOL

\section{DAVIDSON INSTITUTE WORKING PAPER SERIES - Most Recent Papers}

The entire Working Paper Series is available at: www.wdi.bus.umich.edu

CURRENT AS OF 5/30/01

\begin{tabular}{|c|c|c|}
\hline Publication & Authors & Date \\
\hline $\begin{array}{l}\text { No. } 377 \text { Some Explanations for Changes in the Distribution of } \\
\text { Household Income in Slovakia: } 1988 \text { and } 1996\end{array}$ & $\begin{array}{l}\text { Thesia Garner and Katherine } \\
\text { Terrell }\end{array}$ & May 2001 \\
\hline $\begin{array}{l}\text { No. } 376 \text { Competition and Enterprise Performance in Transition } \\
\text { Economies: Evidence from a Cross-country Survey }\end{array}$ & $\begin{array}{l}\text { Wendy Carlin, Steven Fries, } \\
\text { Mark Schaffer and Paul Seabright }\end{array}$ & May 2001 \\
\hline $\begin{array}{l}\text { No. } 375 \text { Why More is Actually Less: New Interpretations of China's } \\
\text { Labor-Intensive FDI }\end{array}$ & Yasheng Huang & May 2001 \\
\hline No. 374 Economic Fragmentation and FDI in China & Yasheng Huang & May 2001 \\
\hline $\begin{array}{l}\text { No. } 373 \text { Earnings Disparities in the Czech Republic: Evidence of the } \\
\text { Past Decade and Cross-National Comparison }\end{array}$ & Jiri Vecernik & May 2001 \\
\hline $\begin{array}{l}\text { No. } 372 \text { Economic Reform, Democracy and Growth During Post- } \\
\text { Communist Transition }\end{array}$ & Jan Fidrmuc & Mar. 2001 \\
\hline $\begin{array}{l}\text { No. } 371 \text { Do Multinational Enterprises Substitute Parent Jobs for Foreign } \\
\text { Ones? Evidence from Firm Level Panel Data }\end{array}$ & Jozef Konings and Alan Murphye & Apr. 2001 \\
\hline $\begin{array}{l}\text { No. } 370 \text { From Needs to the Market: Changing Inequality of Household } \\
\text { Income in the Czech Transition }\end{array}$ & Jiri Vecernik & Apr. 2001 \\
\hline $\begin{array}{l}\text { No. } 369 \text { Competition and Corporate Governance: Substitutes or } \\
\text { Complements? Evidence from the Warsaw Stock Exchange }\end{array}$ & $\begin{array}{l}\text { Irena Grosfeld and Thierry } \\
\text { Tressel }\end{array}$ & Mar. 2001 \\
\hline $\begin{array}{l}\text { No. } 368 \text { Multinational Corporations as Catalyst for Industrial } \\
\text { Development: The Case of Poland }\end{array}$ & $\begin{array}{l}\text { Carlo Altomonte and Laura } \\
\text { Resmini }\end{array}$ & Feb. 2001 \\
\hline No. 367 A Multi-Task Theory of the State Enterprise Reform & $\begin{array}{l}\text { Chong-En Bai, David D. Li, } \\
\text { Zhigang Tao, and Yijiang Wang }\end{array}$ & Mar. 2001 \\
\hline No. 366 Confidence Building in Emerging Stock Markets & $\begin{array}{l}\text { Enrico C. Perotti, Luc Laeven, } \\
\text { and Pieter van Oijen }\end{array}$ & Dec. 2000 \\
\hline $\begin{array}{l}\text { No. } 365 \text { Incentive Contracting versus Ownership Reforms: Evidence } \\
\text { from China's Township and Village Enterprises }\end{array}$ & $\begin{array}{l}\text { Chun Chang, Brian McCall, and } \\
\text { Yijang Wang }\end{array}$ & Nov. 2000 \\
\hline $\begin{array}{l}\text { No. } 364 \text { Individual Pay and Outside Options: Evidence from the Polish } \\
\text { Labour Force Survey }\end{array}$ & $\begin{array}{l}\text { Fiona Duffy and Patrick Paul } \\
\text { Walsh }\end{array}$ & Mar. 2001 \\
\hline $\begin{array}{l}\text { No. } 363 \text { Investment, Credit Rationing and the Soft Budget Constraint: } \\
\text { Evidence from Czech Panel Data (revised Davidson Institute Working } \\
\text { Paper No. 60a) }\end{array}$ & Lubomír Lízal and Jan Svejnar & Feb. 2001 \\
\hline $\begin{array}{l}\text { No. } 362 \text { A Network Perspective on Inter-Organizational Transfer of } \\
\text { R\&D Capabilities: A Study of International Joint Ventures in Chinese } \\
\text { Automobile Industry }\end{array}$ & $\begin{array}{l}\text { Zheng Zhao, Jaideep Anand and } \\
\text { Will Mitchell }\end{array}$ & Feb. 2001 \\
\hline $\begin{array}{l}\text { No. } 361 \text { Network Restructuring and Firm Creation in East-Central } \\
\text { Europe: A Public-Private Venture }\end{array}$ & Gerald A. McDermott & Dec. 2000 \\
\hline $\begin{array}{l}\text { No. } 360 \text { Responses of Private and Public Schools to Voucher Funding: } \\
\text { The Czech and Hungarian Experience }\end{array}$ & $\begin{array}{l}\text { Randall K. Filer and Daniel } \\
\text { Münich }\end{array}$ & Oct. 2000 \\
\hline $\begin{array}{l}\text { No. } 359 \text { Labor Market Uncertainty and Private Sector Labor Supply in } \\
\text { Russia }\end{array}$ & Steven Stillman & Sept. 2000 \\
\hline $\begin{array}{l}\text { No. } 358 \text { Russian Roulette-Expenditure Inequality and Instability in } \\
\text { Russia, 1994-1998 }\end{array}$ & Branko Jovanovic & Sept. 2000 \\
\hline No. 357 Dealing with the Bad Loans of the Chinese Banks & John P. Bonin and Yiping Huang & Jan. 2001 \\
\hline No. 356 Retail Banking in Hungary: A Foreign Affair? & John P. Bonin and István Ábel & Dec. 2000 \\
\hline $\begin{array}{l}\text { No. } 355 \text { Optimal Speed of Transition: Micro Evidence from the Czech } \\
\text { Republic }\end{array}$ & $\begin{array}{l}\text { Stepan Jurajda and Katherine } \\
\text { Terrell }\end{array}$ & Dec. 2000 \\
\hline
\end{tabular}




\begin{tabular}{|c|c|c|}
\hline No. 354 Political Instability and Growth in Dictatorships & $\begin{array}{l}\text { Jody Overland, Kenneth L. } \\
\text { Simons and Michael Spagat }\end{array}$ & Nov. 2000 \\
\hline No. 353 Disintegration and Trade & Jarko Fidrmuc and Jan Fidrmuc & Nov. 2000 \\
\hline $\begin{array}{l}\text { No. } 352 \text { Social Capital and Entrepreneurial Performance in Russia: A } \\
\text { Panel Study }\end{array}$ & Bat Batjargal & Dec. 2000 \\
\hline $\begin{array}{l}\text { No. 351 Entrepreneurial Versatility, Resources and Firm Performance in } \\
\text { Russia: A Panel Study }\end{array}$ & Bat Batjargal & Dec. 2000 \\
\hline $\begin{array}{l}\text { No. } 350 \text { The Dynamics of Entrepreneurial Networks in a Transitional } \\
\text { Economy: The Case of Russia }\end{array}$ & Bat Batjargal & Dec. 2000 \\
\hline $\begin{array}{l}\text { No. 349a R\&D and Technology Spillovers via FDI: Innovation and } \\
\text { Absorptive Capacity }\end{array}$ & Yuko Kinoshita & Apr. 2001 \\
\hline $\begin{array}{l}\text { No. } 349 \text { R\&D and Technology Spillovers via FDI: Innovation and } \\
\text { Absorptive Capacity }\end{array}$ & Yuko Kinoshita & Nov. 2000 \\
\hline $\begin{array}{l}\text { No. } 348 \text { Microeconomic aspects of Economic Growth in Eastern } \\
\text { Europe and the Former Soviet Union, 1950-2000 }\end{array}$ & Sergei Guriev and Barry W. Ickes & Nov. 2000 \\
\hline $\begin{array}{l}\text { No. } 347 \text { Effective versus Statutory Taxation: Measuring Effective Tax } \\
\text { Administration in Transition Economies }\end{array}$ & $\begin{array}{l}\text { Mark E. Schaffer and Gerard } \\
\text { Turley }\end{array}$ & Nov. 2000 \\
\hline $\begin{array}{l}\text { No. } 346 \text { Objectives and Constraints of Entrepreneurs: Evidence from } \\
\text { Small and Medium Size Enterprises in Russia and Bulgaria }\end{array}$ & $\begin{array}{l}\text { Francesca Pissarides, Miroslav } \\
\text { Singer and Jan Svejnar }\end{array}$ & Oct. 2000 \\
\hline No. 345 Corruption and Anticorruption in the Czech Republic & $\begin{array}{l}\text { Lubomír Lízal and Evžen } \\
\text { Kočenda }\end{array}$ & Oct. 2000 \\
\hline No. 344 The Effects of Direct Foreign Investment on Domestic Firms & Jozef Konings & Oct. 2000 \\
\hline No. 343 On the Identification of Relative Wage Rigidity Dynamics & Patrick A. Puhani & Oct. 2000 \\
\hline $\begin{array}{l}\text { No. } 342 \text { The Determinants of Foreign Direct Investment in Transition } \\
\text { Economies }\end{array}$ & Alan A. Bevan and Saul Estrin & Oct. 2000 \\
\hline No. 341 The Global Spread of Stock Exchanges, 1980-1998 & Klaus Weber and Gerald F. Davis & Nov. 2000 \\
\hline $\begin{array}{l}\text { No. } 340 \text { The Costs and Benefits of Euro-isation in Central-Eastern } \\
\text { Europe Before or Instead of EMU Membership }\end{array}$ & D. Mario Nuti & Oct. 2000 \\
\hline No. 339 Debt Overhang and Barter in Russia & $\begin{array}{l}\text { Sergei Guriev, Igor Makarov and } \\
\text { Mathilde Maurel }\end{array}$ & Sept. 2000 \\
\hline $\begin{array}{l}\text { No. } 338 \text { Firm Performance and the Political Economy of Corporate } \\
\text { Governance: Survey Evidence for Bulgaria, Hungary, Slovakia and } \\
\text { Slovenia }\end{array}$ & $\begin{array}{l}\text { Patrick Paul Walsh and Ciara } \\
\text { Whela }\end{array}$ & July 2000 \\
\hline No. 337 Investment and Instability & $\begin{array}{l}\text { Nauro F. Campos and Jeffrey B. } \\
\text { Nugent }\end{array}$ & May 2000 \\
\hline $\begin{array}{l}\text { No. } 336 \text { The Evolution of the Insurance Sector in Central and } \\
\text { Eastern Europe and the former Soviet Union }\end{array}$ & Robert B.K. Pye & Aug. 2000 \\
\hline $\begin{array}{l}\text { No. } 335 \text { Institutional Technology and the Chains of Trust: Capital } \\
\text { Markets and Privatization in Russia and the Czech Republic }\end{array}$ & Bruce Kogut and Andrew Spicer & Aug. 2000 \\
\hline No. 334 The Evolution of Market Integration in Russia & $\begin{array}{l}\text { Daniel Berkowitz and David N. } \\
\text { DeJong }\end{array}$ & Aug. 2000 \\
\hline No. 333 Efficiency and Market Share in Hungarian Corporate Sector & László Halpern and Gábor Körösi & July 2000 \\
\hline No. 332 Search-Money-and-Barter Models of Financial Stabilization & $\begin{array}{l}\text { S.I. Boyarchenko and S.Z. } \\
\text { Levendorskii }\end{array}$ & July 2000 \\
\hline $\begin{array}{l}\text { No. } 331 \text { Worker Training in a Restructuring Economy: Evidence from } \\
\text { the Russian Transition }\end{array}$ & $\begin{array}{l}\text { Mark C. Berger, John S. Earle } \\
\text { and Klara Z. Sabirianova }\end{array}$ & Aug. 2000 \\
\hline $\begin{array}{l}\text { No. } 330 \text { Economic Development in Palanpur 1957-1993: A Sort of } \\
\text { Growth }\end{array}$ & Peter Lanjouw & Aug. 2000 \\
\hline $\begin{array}{l}\text { No. } 329 \text { Trust, Organizational Controls, Knowledge Acquisition from } \\
\text { the Foreign Parents, and Performance in Vietnamese International Joint } \\
\text { Ventures }\end{array}$ & $\begin{array}{l}\text { Marjorie A. Lyles, Le Dang } \\
\text { Doanh, and Jeffrey Q. Barden }\end{array}$ & June 2000 \\
\hline $\begin{array}{l}\text { No. } 328 \text { Comparative Advertising in the Global Marketplace: The } \\
\text { Effects of Cultural Orientation on Communication }\end{array}$ & $\begin{array}{l}\text { Zeynep Gürhan-Canli and } \\
\text { Durairaj Maheswaran }\end{array}$ & Aug. 2000 \\
\hline No. 327 Post Privatization Enterprise Restructuring & Morris Bornstein & July 2000 \\
\hline No. 326 Who is Afraid of Political Instability? & $\begin{array}{l}\text { Nauro F. Campos and Jeffrey B. } \\
\text { Nugent }\end{array}$ & July 2000 \\
\hline
\end{tabular}




\begin{tabular}{|c|c|c|}
\hline No. 325 Business Groups, the Financial Market and Modernization & Raja Kali & June 2000 \\
\hline $\begin{array}{l}\text { No. } 324 \text { Restructuring with What Success? A Case Study of Russian } \\
\text { Firms }\end{array}$ & Susan Linz & July 2000 \\
\hline $\begin{array}{l}\text { No. } 323 \text { Priorities and Sequencing in Privatization: Theory and } \\
\text { Evidence from the Czech Republic }\end{array}$ & $\begin{array}{l}\text { Nandini Gupta, John C. Ham and } \\
\text { Jan Svejnar }\end{array}$ & May 2000 \\
\hline $\begin{array}{l}\text { No. } 322 \text { Liquidity, Volatility, and Equity Trading Costs Across } \\
\text { Countries and Over Time }\end{array}$ & $\begin{array}{l}\text { Ian Domowitz, Jack Glen and } \\
\text { Ananth Madhavan }\end{array}$ & Mar. 2000 \\
\hline $\begin{array}{l}\text { No. } 321 \text { Equilibrium Wage Arrears: A Theoretical and Empirical } \\
\text { Analysis of Institutional Lock-In }\end{array}$ & $\begin{array}{l}\text { John S. Earle and Klara Z. } \\
\text { Sabirianova }\end{array}$ & Oct. 2000 \\
\hline No. 320 Rethinking Marketing Programs for Emerging Markets & $\begin{array}{l}\text { Niraj Dawar and Amitava } \\
\text { Chattopadhyay }\end{array}$ & June 2000 \\
\hline $\begin{array}{l}\text { No. } 319 \text { Public Finance and Low Equilibria in Transition Economies: } \\
\text { the Role of Institutions }\end{array}$ & $\begin{array}{l}\text { Daniel Daianu and Radu } \\
\text { Vranceanu }\end{array}$ & June 2000 \\
\hline $\begin{array}{l}\text { No. } 318 \text { Some Econometric Evidence on the Effectiveness of Active } \\
\text { Labour Market Programmes in East Germany }\end{array}$ & $\begin{array}{l}\text { Martin Eichler and Michael } \\
\text { Lechner }\end{array}$ & June 2000 \\
\hline No. 317 A Model of Russia’s "Virtual Economy" & R.E Ericson and B.W Ickes & May 2000 \\
\hline $\begin{array}{l}\text { No. } 316 \text { Financial Institutions, Financial Contagion, and Financial } \\
\text { Crises }\end{array}$ & $\begin{array}{l}\text { Haizhou Huang and Chenggang } \\
\mathrm{Xu}\end{array}$ & Mar. 2000 \\
\hline $\begin{array}{l}\text { No. } 315 \text { Privatization versus Regulation in Developing Economies: The } \\
\text { Case of West African Banks }\end{array}$ & $\begin{array}{l}\text { Jean Paul Azam, Bruno Biais, and } \\
\text { Magueye Dia }\end{array}$ & Feb. 2000 \\
\hline $\begin{array}{l}\text { No. } 314 \text { Is Life More Risky in the Open? Household Risk-Coping and } \\
\text { the Opening of China's Labor Markets }\end{array}$ & John Giles & Apr. 2000 \\
\hline $\begin{array}{l}\text { No. } 313 \text { Networks, Migration and Investment: Insiders and Outsiders in } \\
\text { Tirupur's Production Cluster }\end{array}$ & $\begin{array}{l}\text { Abhijit Banerjee and Kaivan } \\
\text { Munshi }\end{array}$ & Mar. 2000 \\
\hline $\begin{array}{l}\text { No. } 312 \text { Computational Analysis of the Impact on India of the Uruguay } \\
\text { Round and the Forthcoming WTO Trade Negotiations }\end{array}$ & $\begin{array}{l}\text { Rajesh Chadha, Drusilla K. } \\
\text { Brown, Alan V. Deardorff and } \\
\text { Robert M. Stern }\end{array}$ & Mar. 2000 \\
\hline No. 311 Subsidized Jobs for Unemployed Workers in Slovakia & Jan. C. van Ours & May 2000 \\
\hline No. 310 Determinants of Managerial Pay in the Czech Republic & $\begin{array}{l}\text { Tor Eriksson, Jaromir Gc } \\
\text { and Pavel Mrazek }\end{array}$ & May 2000 \\
\hline $\begin{array}{l}\text { No. } 309 \text { The Great Human Capital Reallocation: An Empirical Analysis } \\
\text { of Occupational Mobility in Transitional Russia }\end{array}$ & Klara Z. Sabirianova & Oct. 2000 \\
\hline No. 308 Economic Development, Legality, and the Transplant Effect & $\begin{array}{l}\text { Daniel Berkowitz, Katharina } \\
\text { Pistor, and Jean-Francois Richard }\end{array}$ & Feb. 2000 \\
\hline $\begin{array}{l}\text { No. } 307 \text { Community Participation, Teacher Effort, and Educational } \\
\text { Outcome: The Case of El Salvador's EDUCO Program }\end{array}$ & Yasuyuki Sawada & Nov. 1999 \\
\hline No. 306 Gender Wage Gap and Segregation in Late Transition & Stepan Jurajda & May 2000 \\
\hline $\begin{array}{l}\text { No. } 305 \text { The Gender Pay Gap in the Transition from Communism: } \\
\text { Some Empirical Evidence }\end{array}$ & Andrew Newell and Barry Reilly & May 2000 \\
\hline No. 304 Post-Unification Wage Growth in East Germany & Jennifer Hunt & Nov. 1998 \\
\hline $\begin{array}{l}\text { No. } 303 \text { How Does Privatization Affect Workers? The Case of the } \\
\text { Russian Mass Privatization Program }\end{array}$ & Elizabeth Brainerd & May 2000 \\
\hline $\begin{array}{l}\text { No. } 302 \text { Liability for Past Environmental Contamination and } \\
\text { Privatization }\end{array}$ & Dietrich Earnhart & Mar. 2000 \\
\hline No. 301 Varieties, Jobs and EU Enlargement & $\begin{array}{l}\text { Tito Boeri and Joaquim Oliveira } \\
\text { Martins }\end{array}$ & May 2000 \\
\hline No. 300 Employer Size Effects in Russia & Todd Idson & Apr. 2000 \\
\hline $\begin{array}{l}\text { No. } 299 \text { Information Complements, Substitutes, and Strategic Product } \\
\text { Design }\end{array}$ & $\begin{array}{l}\text { Geoffrey G. Parker and Marshall } \\
\text { W. Van Alstyne }\end{array}$ & Mar. 2000 \\
\hline $\begin{array}{l}\text { No. } 298 \text { Markets, Human Capital, and Inequality: Evidence from Rural } \\
\text { China }\end{array}$ & $\begin{array}{l}\text { Dwayne Benjamin, Loren Brandt, } \\
\text { Paul Glewwe, and Li Guo }\end{array}$ & May 2000 \\
\hline No. 297 Corporate Governance in the Asian Financial Crisis & $\begin{array}{l}\text { Simon Johnson, Peter Boone, } \\
\text { Alasdair Breach, and Eric } \\
\text { Friedman }\end{array}$ & Nov. 1999 \\
\hline No. 296 Competition and Firm Performance: Lesso & J. David Brown and John S. Earle & Mar. 2000 \\
\hline
\end{tabular}




\begin{tabular}{|c|c|c|}
\hline No. 295 Wage Determination in Russia: An Econometric Investigation & $\begin{array}{l}\text { Peter J. Luke and Mark E. } \\
\text { Schaffer }\end{array}$ & Mar. 2000 \\
\hline $\begin{array}{l}\text { No. } 294 \text { Can Banks Promote Enterprise Restructuring?: Evidence From } \\
\text { a Polish Bank's Experience }\end{array}$ & John P. Bonin and Bozena Leven & Mar. 2000 \\
\hline No. 293 Why do Governments Sell Privatised Companies Abroad? & $\begin{array}{l}\text { Bernardo Bortolotti, Marcella } \\
\text { Fantini and Carlo Scarpa }\end{array}$ & Mar. 2000 \\
\hline $\begin{array}{l}\text { No. } 292 \text { Going Public in Poland: Case-by-Case Privatizations, Mass } \\
\text { Privatization and Private Sector Initial Public Offerings }\end{array}$ & Wolfgang Aussenegg & Dec. 1999 \\
\hline $\begin{array}{l}\text { No. 291 a Institutional Technology and the Chains of Trust: Capital } \\
\text { Markets and Privatization in Russia and the Czech Republic }\end{array}$ & Bruce Kogut and Andrew Spicer & Feb. 2001 \\
\hline $\begin{array}{l}\text { No. } 291 \text { Institutional Technology and the Chains of Trust: Capital } \\
\text { Markets and Privatization in Russia and the Czech Republic }\end{array}$ & Bruce Kogut and Andrew Spicer & Mar. 1999 \\
\hline No. 290 Banking Crises and Bank Rescues: The Effect of Reputation & Jenny Corbett and & Jan. 2000 \\
\hline $\begin{array}{l}\text { No. } 289 \text { Do Active Labor Market Policies Help Unemployed Workers to } \\
\text { Find and Keep Regular Jobs? }\end{array}$ & Jan C. van Ours & Feb. 2000 \\
\hline No. 288 Consumption Patterns of the New Elite in Zimbabwe & Russell Belk & Feb. 2000 \\
\hline $\begin{array}{l}\text { No. } 287 \text { Barter in Transition Economies: Competing Explanations } \\
\text { Confront Ukranian Data }\end{array}$ & $\begin{array}{l}\text { Dalia Marin, Daniel Kaufmann } \\
\text { and Bogdan Gorochowskij }\end{array}$ & Jan. 2000 \\
\hline $\begin{array}{l}\text { No. } 286 \text { The Quest for Pension Reform: Poland's Security through } \\
\text { Diversity }\end{array}$ & $\begin{array}{l}\text { Marek Góra and Michael } \\
\text { Rutkowski }\end{array}$ & Jan. 2000 \\
\hline No. 285 Disorganization and Financial Collapse & $\begin{array}{l}\text { Dalia Marin and Monika } \\
\text { Schnitzer }\end{array}$ & Oct. 1999 \\
\hline No. 284 Coordinating Changes in M-form and U-form Organizations & $\begin{array}{l}\text { Yingyi Qian, Gérard Roland and } \\
\text { Chenggang Xu }\end{array}$ & May 1999 \\
\hline $\begin{array}{l}\text { No. } 283 \text { Why Russian Workers Do Not Move: Attachment of Workers } \\
\text { Through In-Kind Payments }\end{array}$ & Guido Friebel and Sergei Guriev & Oct. 1999 \\
\hline No. 282 Lessons From Fiascos in Russian Corporate Governance & $\begin{array}{l}\text { Merritt B. Fox an } \\
\text { Heller }\end{array}$ & Oct. 1999 \\
\hline $\begin{array}{l}\text { No. } 281 \text { Income Distribu } \\
\text { Safety Net During Econo }\end{array}$ & $\begin{array}{l}\text { Michael Alexeev and James } \\
\text { Leitzel }\end{array}$ & Mar. 1999 \\
\hline $\begin{array}{l}\text { No. 280: Starting Positions, Reform Speed, and Economic Outcomes in } \\
\text { Transitioning Economies }\end{array}$ & William Hallagan and Zhang Jun & Jan. 2000 \\
\hline No. $279:$ The Value of Prominent Directors & $\begin{array}{l}\text { Yoshiro Miwa \& J. Mark } \\
\text { Ramseyer }\end{array}$ & Oct. 1999 \\
\hline No. 278: The Sy & Kornai & Apr. 1998 \\
\hline $\begin{array}{l}\text { No. 277: The Developmental Consequences of Foreign Direct } \\
\text { Investment in the Transition from Socialism to Capitalism: The } \\
\text { Performance of Foreign Owned Firms in Hungary }\end{array}$ & Lawrence Peter King & Sept. 1999 \\
\hline $\begin{array}{l}\text { No. 276: Stability and Disorder: An Evolutionary Analysis of Russia's } \\
\text { Virtual Economy }\end{array}$ & $\begin{array}{l}\text { Clifford Gaddy and Barry W. } \\
\text { Ickes }\end{array}$ & Nov. 1999 \\
\hline $\begin{array}{l}\text { No. 275: Limiting Government Predation Through Anonymous } \\
\text { Banking: A Theory with Evidence from China. }\end{array}$ & $\begin{array}{l}\text { Chong-En Bai, David D. Li, } \\
\text { Yingyi Qian and Yijiang Wang }\end{array}$ & July 1999 \\
\hline No. 274: Transit & Boeri & Dec. 1999 \\
\hline $\begin{array}{l}\text { No. 273: Sectoral Restructuring and Labor Mobility: A Comparative } \\
\text { Look at the Czech Republic }\end{array}$ & Vit Sorm and Katherine Terrell & Nov. 1999 \\
\hline $\begin{array}{l}\text { No. 272: Published in: Journal of Comparative Economics "Returns to } \\
\text { Human Capital Under the Communist Wage Grid and During the } \\
\text { Transition to a Market Economy" Vol. 27, pp. 33-60 } 1999 .\end{array}$ & $\begin{array}{l}\text { Daniel Munich, Jan Svejnar and } \\
\text { Katherine Terrell }\end{array}$ & Oct. 1999 \\
\hline $\begin{array}{l}\text { No. 271: Barter in Russia: Liquidity Shortage Versus Lack of } \\
\text { Restructuring }\end{array}$ & $\begin{array}{l}\text { Sophie Brana and Mathilde } \\
\text { Maurel }\end{array}$ & June 1999 \\
\hline $\begin{array}{l}\text { No. 270: Tests for Efficient Financial Intermediation with Application to } \\
\text { China }\end{array}$ & Albert Park and Kaja Sehrt & Mar. 1999 \\
\hline $\begin{array}{l}\text { No. 269a: Russian Privatization and Corporate Governance: What Went } \\
\text { Wrong? }\end{array}$ & $\begin{array}{l}\text { Bernard Black, Reinier Kraakman } \\
\text { and Anna Tarassova }\end{array}$ & May 2000 \\
\hline $\begin{array}{l}\text { No. 269: Russian Privatization and Corporate Governance: What Went } \\
\text { Wrong? }\end{array}$ & $\begin{array}{l}\text { Bernard Black, Reinier Kraakman } \\
\text { and Anna Tarassova }\end{array}$ & Sept. 1999 \\
\hline
\end{tabular}

